\title{
Empirical Testing of Real Option-Pricing Models Using
}

\section{Land Price Index in Japan}

\author{
by \\ Ritsuko Yamazaki \\ M.Eng in Urban Engineering, Graduate School, University of Tokyo (1996) \\ B.Eng in Urban Engineering, University of Tokyo (1993) \\ Submitted to the Department of Urban Studies and Planning \\ in partial fulfillment of the requirements for the degree of
}

Master in City Planning

at the

MASSACHUSETTS INSTITUTE OF TECHNOLOGY

June 2000

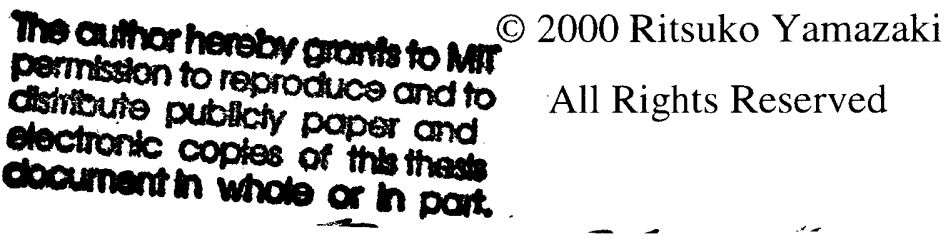

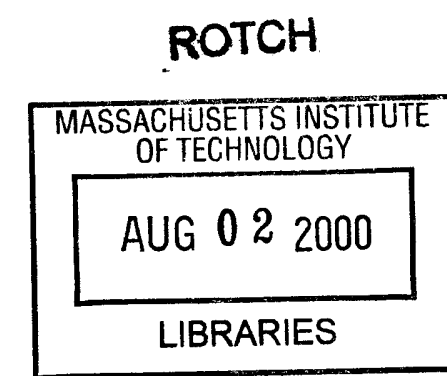

Author

Department of Urban Studies and Planning May 18,2000

Certified by

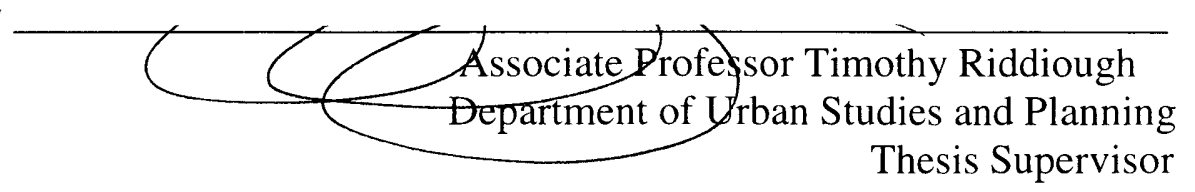

Accepted by

Associate Professor Paul Smoke Chair, MCP Committee

Department of Urban Studies and Planning 


\title{
Empirical Testing of Real Option-Pricing Models
}

\section{Using Land Price Index in Japan}

\author{
by \\ Ritsuko Yamazaki \\ Submitted to the Department of Urban Studies and Planning \\ on May 18, 2000 in partial fulfillment of the requirements for the degree of \\ Master in City Planning
}

\begin{abstract}
The purpose of this research is to examine the way uncertainty plays a role in built land prices. This paper provides basic real option pricing models of land prices on the demand side in central Tokyo. The model in this research analyzes micro land prices covering individual lot data provided by the Land Price Index. Since land prices are determined by both macro economic environment and micro lot-specific attributes, this paper utilizes both time-series economic data and cross-sectional lot-specific data. The model incorporates both time-series (macro) and cross-sectional (micro) data including uncertainty terms. In addition to the total uncertainty in asset prices, this research also gives some ideas of cross-sectional uncertainty in land price variations by utilizing cross-sectional amenity variables. These cross-sectional and time-series variables including these two uncertainty variables are pooled and the OLS method is conducted. The data set consists of 4,368 land price data from 1985 through 2000 . The results from the option-based models favor the application of the real option theory in land prices. The total uncertainty with respect to built asset return has a substantial effect on increasing land prices, which implies that an increase in uncertainty leads to an increase in land prices.
\end{abstract}

Thesis Supervisor: Timothy Riddiough

Title: Associate Professor 


\section{Table of Contents}

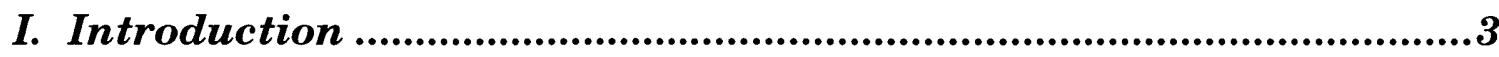

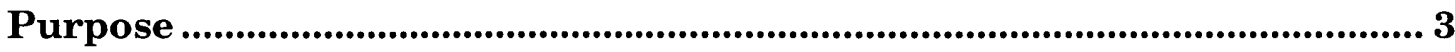

Summary of Model..................................................................................................... 5

Summary of Results...................................................................................................... 6

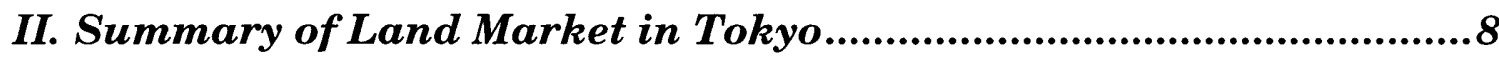

Notes: The Land Price Index ................................................................................ 15

Literature Review................................................................................................. 18

III. Overview of Theories .......................................................................21

Real Options................................................................................................................... 21

Stochastic Process ........................................................................................................ 22

Characteristics of the Option to Invest................................................................ 23

Application to Real Estate Price.............................................................................. 29

Literature Review...................................................................................................... 30

Hedonic Models ............................................................................................................... 34

Pool Data Analysis ..................................................................................................... 35

IV. Model and Data Specification........................................................38

Hedonic Models ............................................................................................................. 38 


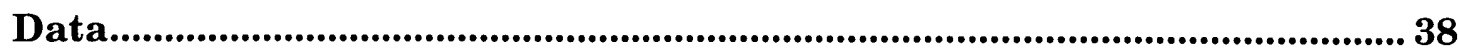

Results and Implications..................................................................... 44

Pool Data Analysis ................................................................................ 46

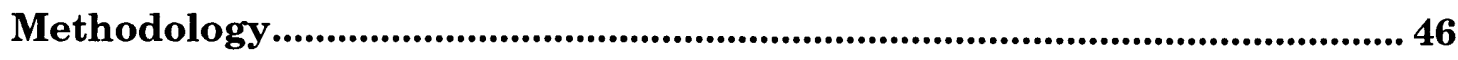

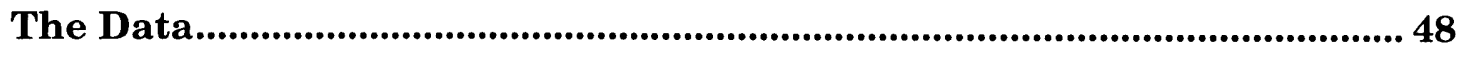

V. Results and Discussion .........................................................54

Time-series Analysis................................................................................ 55

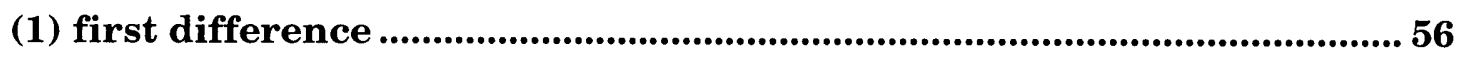

(2) Distributed Lag..............................................................................57

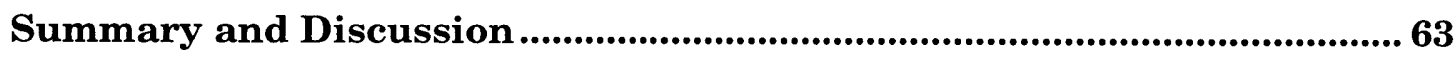

References..............................................................................66 


\section{Introduction}

Lands for residential or commercial uses are priced according to both economic environment and lot-specific attributes including location characteristics. The first factor is examined by time-series data; the second, by cross-sectional data. Over time, the valuation of lot attributes by the market is likely to shift because of income growth, overall inflation, and specific market conditions in the land market. The price variations result from uncertain situations in the future and are classified by the timeseries uncertain component, the cross-section uncertain component, and the combined uncertain component.

Recent research has showed that the option-based model focuses on the uncertainty and can explain phenomena which neo-classical models cannot. For example, real world investment seems less sensitive to interest rate changes and much more sensitive to volatility and uncertainty in the economic environment. The real option theory focuses on the effects of uncertainty in investment and demonstrates that the uncertainty creates the option value: the uncertainty leads to delay in investment on the supply side and a higher asset value on the demand side. On the other hand, the neo-classical theory ignores effects of idiosyncratic risk and only takes systematic risks on the demand side. This paper provides basic real option pricing models of land prices in central Tokyo dealing with time-series and cross-sectional data.

\section{Purpose}

The purpose of this research is to verify that option-based investment models can better explain the pricing of land markets in Japan than can neoclassical models. Real options, which have been valued in the academic literature, include capital investments 
as well as urban developable land. Results from option-based models show that price uncertainty increases investment option value and that the investment threshold also increases to account for the value on any given day. This fact implies that an increase in uncertainty leads to an increase in land prices.

Most empirical tests of existing option-based models dealing with real estate have used aggregated data, such as $\mathrm{NCREIF}^{1}, \mathrm{NAREIT}^{2}$, as well as data relating to nationwide construction. However, real estate investment is affected by local conditions as well as by macro circumstances. Grenadier (1995) analyzes office vacancies and concludes that the level of equilibrium is predominately determined by local, rather than national factors and that random shocks have caused local deviations from equilibrium. He also presents significant contemporaneous correlation of shocks across cities and a dramatic level of persistence in all markets. Thus, in order to examine the role of uncertainty in local investment, regional investment data also should be included.

This research tries to capture the way uncertainty plays a role in built land prices, by combining both micro and macro data. In addition, by utilizing micro data, this research also gives some ideas of cross-sectional uncertainty in land price variations. Note that although this model only explains the demand side, if it is reasonable to assume the elasticity of the supply side is arbitrarily large, it can explain the market equilibrium.

1 National Council of Real Estate Investment Fiduciaries: The NCREIF Property Index consists of both equity and leveraged properties, acquired on behalf of tax-exempt institutions and held in a fiduciary environment. Calculations are based on quarterly returns of individual properties,sorted by geographic areas, and each property's market value is determined by real estate appraisal methodology, consistently applied.

${ }^{2}$ National Association of Real Estate Investment Trusts: The NAREIT Index is the only REIT index to include all 211 REITs currently trading on the New York Stock Exchange, the 


\section{Summary of Model}

Since land prices are determined by both macro economic environment and micro lot-specific attributes, this paper utilizes both time-series economic data and crosssectional lot-specific data. The model in this research analyzes micro land prices in central Tokyo provided in the individual lot data of the Land Price Index ${ }^{3}$. The Index provides prices for each address listed accompanied by other lot-specific attributes. In this paper, these attributes are named "amenity variables." These amenity variables are classified according to two characteristics: lot characteristics such as lot size, the situation of streets attached, zoning, and floor area ratio (FAR); and location characteristics such as its ward and its distance from the closest train station. First, in order to capture cross-sectional uncertainty hedonic models including the amenity variables are estimated by each year and by each sub-region, or ward, in central Tokyo. Next, economic variables are chosen for the model based on the real option theory. These variables include government bond yield, rent yield rate, stock price index for the real estate industry (TPREAL), covariance of daily changes of TPREAL and of comprehensive stock price index (TOPIX), and construction costs. As to uncertainty components, the standard deviation of the TPREAL is employed to represent the total uncertainty of time-series economic environment, and the cross-sectional uncertainty variable is generated by the regression residuals of hedonic models of each year. Then, the cross-sectional amenity variables, the cross-sectional uncertainty variable, and the

NASDAQ National Market System and the American Stock Exchange.

${ }^{3}$ The Land Price Index is the Japanese government's set of benchmark land prices which is annually appraised. This Index provides prices for each address listed accompanied by other lotspecific attributes. (see. Note in the following chapter) 
economic time-series variables are pooled. Assuming that these variables have linear or log-linear relationships with land prices, the ordinary least squares (OLS) method is utilized in three models. First, the level of economic variables is included. Second, in order to transform into stationary process of time-series variables, such as land price variable and the economic variables, differences between levels of these variables and those at the one previous year are included. Third, considering that economic changes can be distributed over years, the distributed lag method is employed.

\section{Summary of Results}

The results favor the application of the real option theory in land prices. Examining the standard coefficients of the economic variables, the option-based pricing models identify the role of uncertainty in land price variations. The findings are that the total uncertainty with respect to built asset return increases the price of land. The standardized coefficients of the total uncertainty $\sigma$ have positive signs and are relatively large in all models. The coefficient of the systematic risk $\sigma_{P M}$ shows a negative sign in all models, which can be explained by both the option theory and the capital asset pricing model, CAPM. The coefficient of construction cost $K$ shows negative in one model that uses lagged terms. Effects of construction cost on land prices can be captured better in models that uses lagged terms than other models because it usually takes more than two years to construct built assets from decision making. The coefficient of the risk-free interest rate $i$ shows both signs: negative in two models, one that uses the level of variables and another uses one difference of variables, and positive in the model that uses lagged terms. This result may be because the interest rate affects option prices in two opposite direction: a lower interest rate 
increases the present value of the cost of investment as well as the option value. The coefficient of the rent yield rate $y$ has a negative sign in all models, which is also explained by both theories. The coefficient of the residual of cross-sectional variable $u$ has negative signs in all models, which may imply that this uncertainty acts as noise in estimates of asset prices. This uncertainty decreases in the current value as well as standard option value ${ }^{4}$ (Childs et al. (2000)).

${ }^{4}$ Note that this noise $u$ is uncertainty in the current prices and the $\sigma$ is total uncertainty in the future prices. 


\section{Summary of Land Market in Tokyo}

The land prices had been constantly increasing before and during the Japanese bubble economy, which means no cycle. After the peak in 1991 at Bubble Era, land value continues to decline and seems to seek the point of its real value. The prices of real estate are now determined more by demand and supply. The risks from investment in real estate made during these "boom" years of the Japanese economy have become obvious and are exemplified by current bad loan problems in Japan. Thus the risks and returns of real estate also need to be more understood like other financial vehicles.

In Japan, the transaction estimation method and the cost method have been long employed to appraise the real estate prices. The transaction method leads the bubble because the appraisal prices are based on the actual transaction prices which tend to involve speculative elements. In order to obtain the real value against the transaction method, the Real Estate Appraisal Standards issued in 1991 suggest apply the DCF method. The ratio of the appraisal price by the DCF method to the price of Land Price Index of highly commercialized areas is about $90 \%$ in the Marunouchi Area in Chuo ward and about $85 \%$ in the Shinjuku Area. This ratio is increasing in the recent years, which means that land prices in highly commercialized areas reflect their earning capacity. Since the late 1990 's, the real estate market has changed dramatically owing to the Japanese-style Big Bang reform plan of financial system and introduction of the real estate securitization. The discount cash flow (DCF) method for evaluation of land has been emphasized in the appraisal process. This method allows the $\mathrm{v}$ alue of real estate to be determined by the generated return, not by the expected fancy capital gains; the price of real estate is getting closer to its real value. 


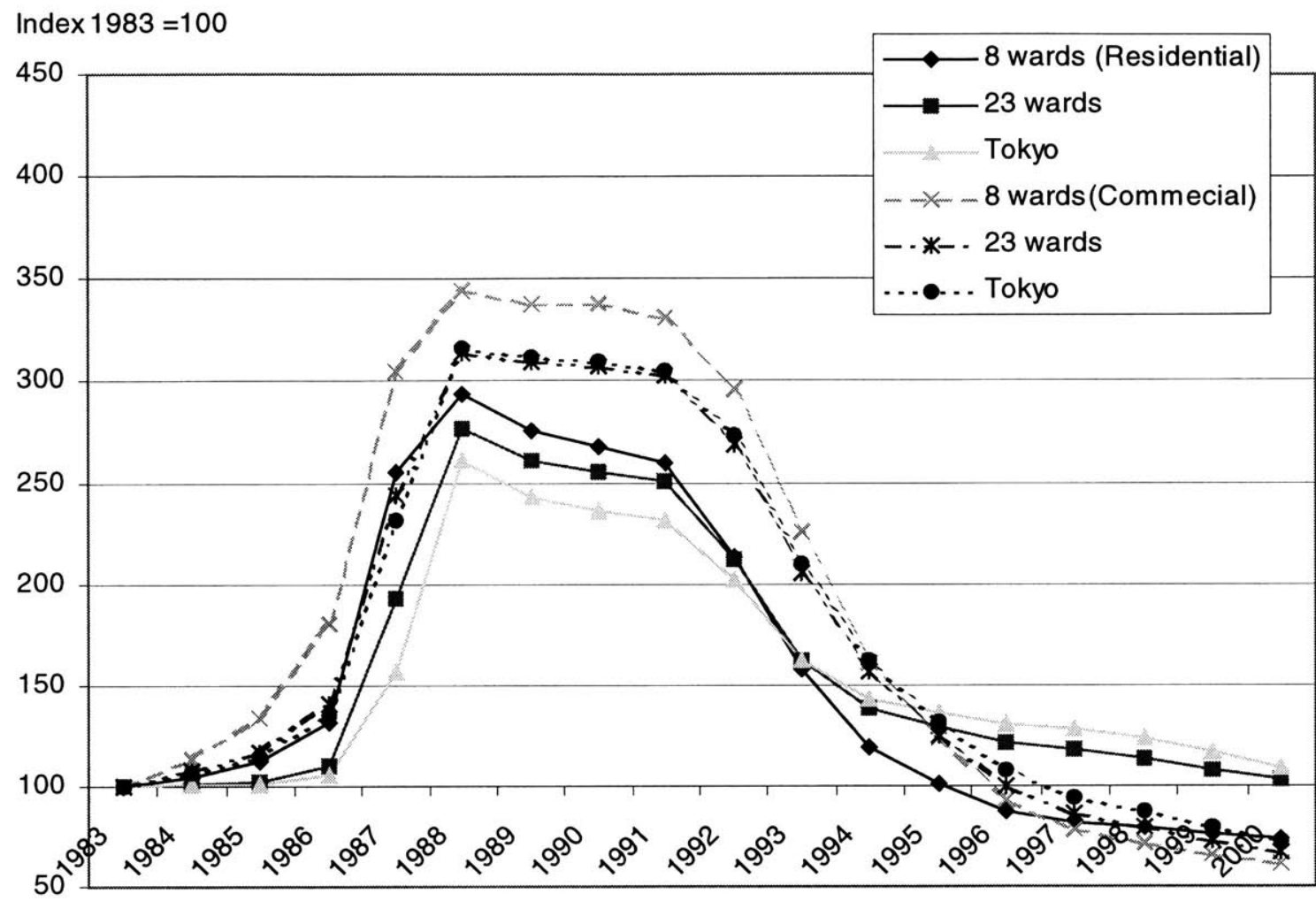

(\%)

year-to year \% change

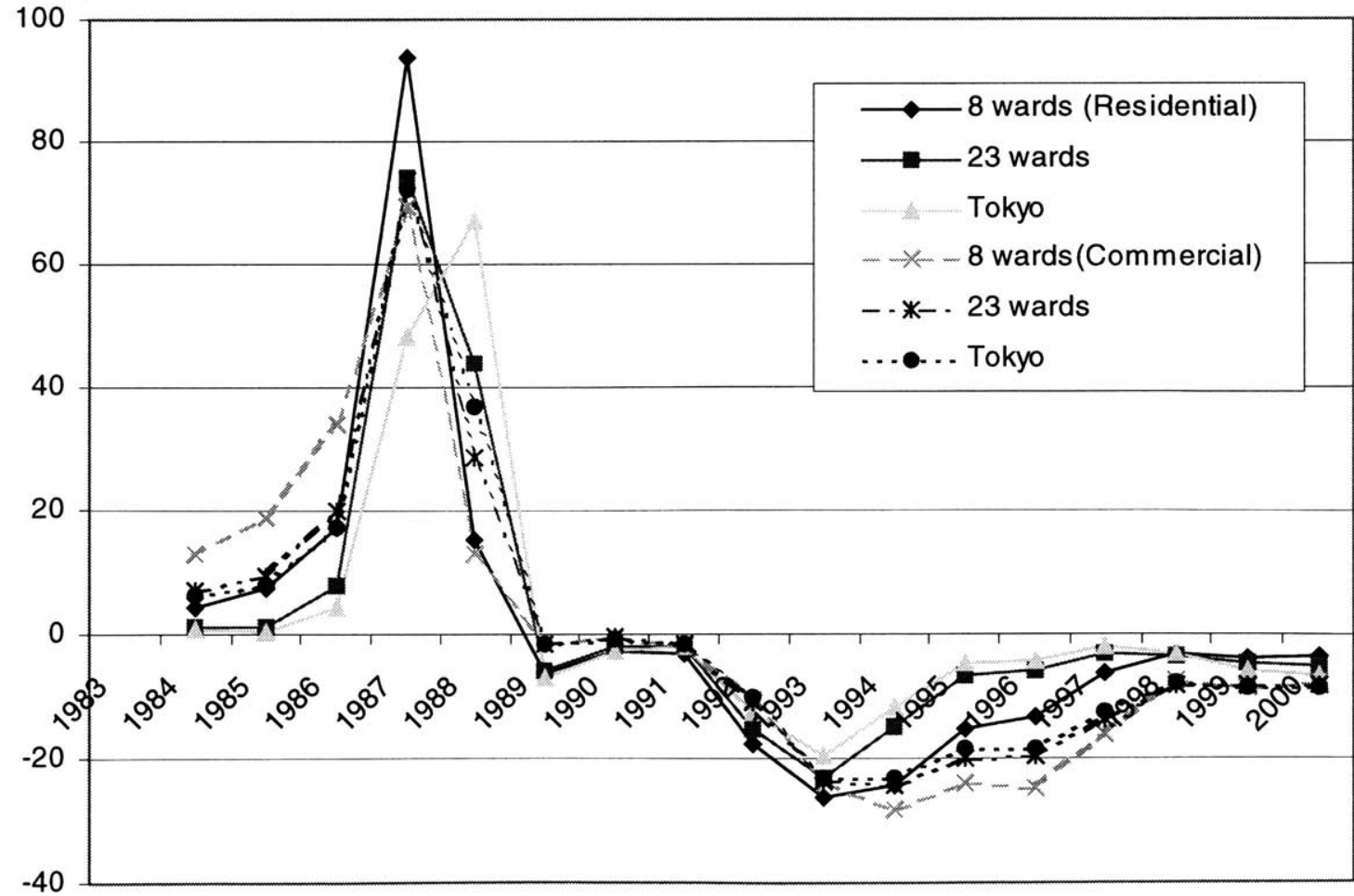

Figure 2-1: Land Price Index of Tokyo 
According to the latest Land Price Index of 2000, the average land price in Tokyo has dropped for nine years [Figure 2-1: Land Price Index of Tokyol. The drop of residential and commercial land prices has shrunk in central Tokyo. However, some prime areas seem to have stopped declining: for example, Ginza, one of the most highly commercialized areas, has an observation point whose price has increased after a twoyear drop. One background fact is that foreign-affiliated companies which expect income from the investments have bought prime lands in central Tokyo. Even among the same areas, only prices of prime lands have increased and the farther from the central, or subway station, prices have still dropped, which has caused bipolarization of land prices according to the location. The drop of commercial land prices has broadened in surrounding Tokyo against the background of tendency to return to the central.

$<$ Real Estate Markets>

(1) Gross Domestic Products (GDP)

Seen over the long-run, year-to-year percentage change of the Land Price Index and GDP growth rate have similar movements in the past with some lags. The Index is much more volatile than the GDP growth. In the next section, effects by growth rate on land prices are provided form the real option theory Figure 2-2: Land Price Index and GDP Growth Rate in Tokyol. 
Annual \% Change of Land Price Index and GDP Growth Rate in Tokyo

(\%)

(in real terms)

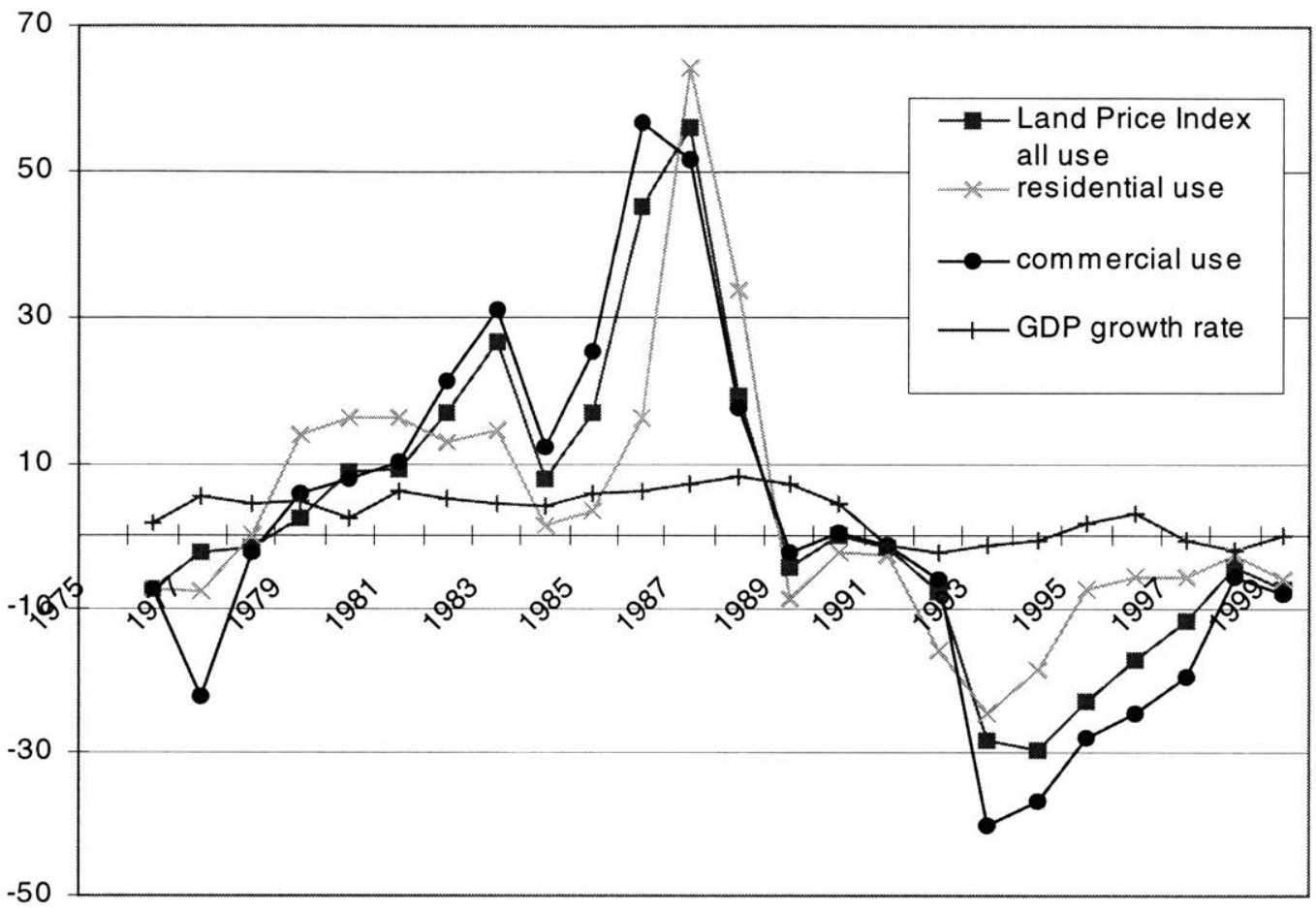

Figure 2-2: Land Price Index and GDP Growth Rate in Tokyo

(2) Financial (Stock) Markets

From the fact that the land assets take the second largest part, after the financial assets, in the national assets ${ }^{5}$ [Figure 2-3: National Assets]. The Figure 2-4 shows that the average price of the Index of Tokyo prefecture and the prices of Stock Index on the first trading day of the years. They have moved together for past 31 years. The correlation between prices of the Land Price index and those of TPREAL Index is higher than correlation between Land Price Index and TOPIX Index ${ }^{6}$. Therefore, TPREAL can be a good indicator for land (where built assets exist) price movements.

5 The ratio of land assets to national gross assets increased through the bubble and reached $33.1 \%$ in 1991. After 1991, it was affected by falling land prices and has gradually decreased to $22.4 \%$ in 1997 (financial assets excluding stocks 53.5\% and housing assets $3.6 \%$ ). 


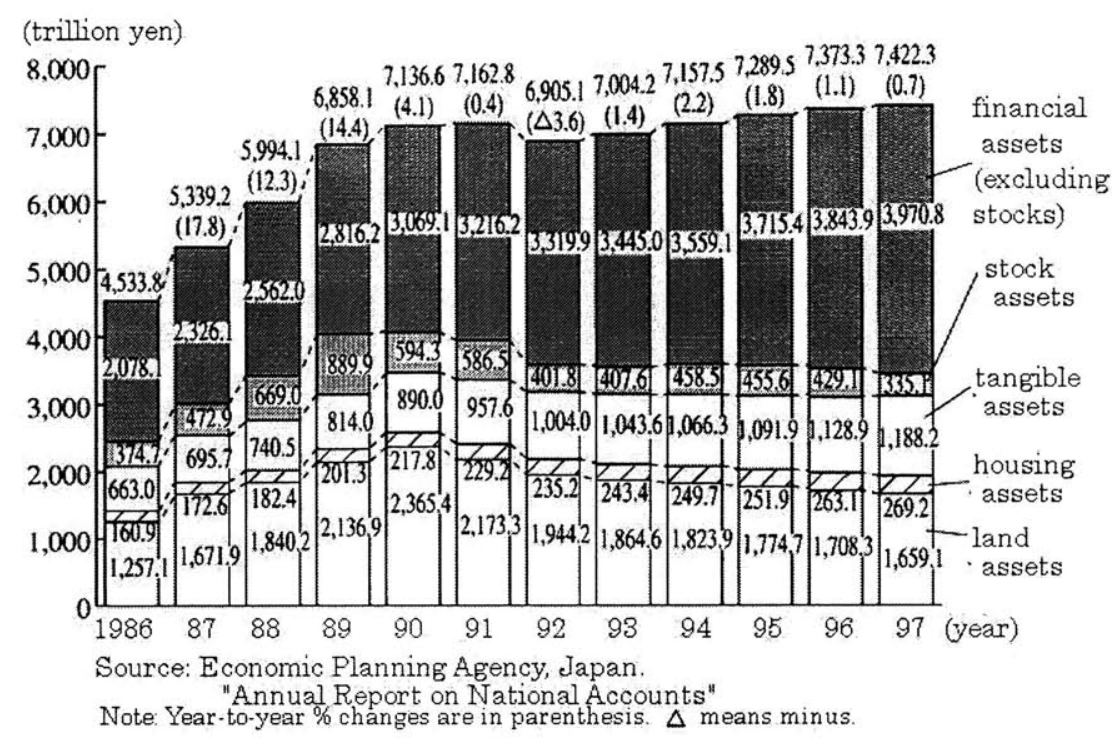

Figure 2-3 National Assets

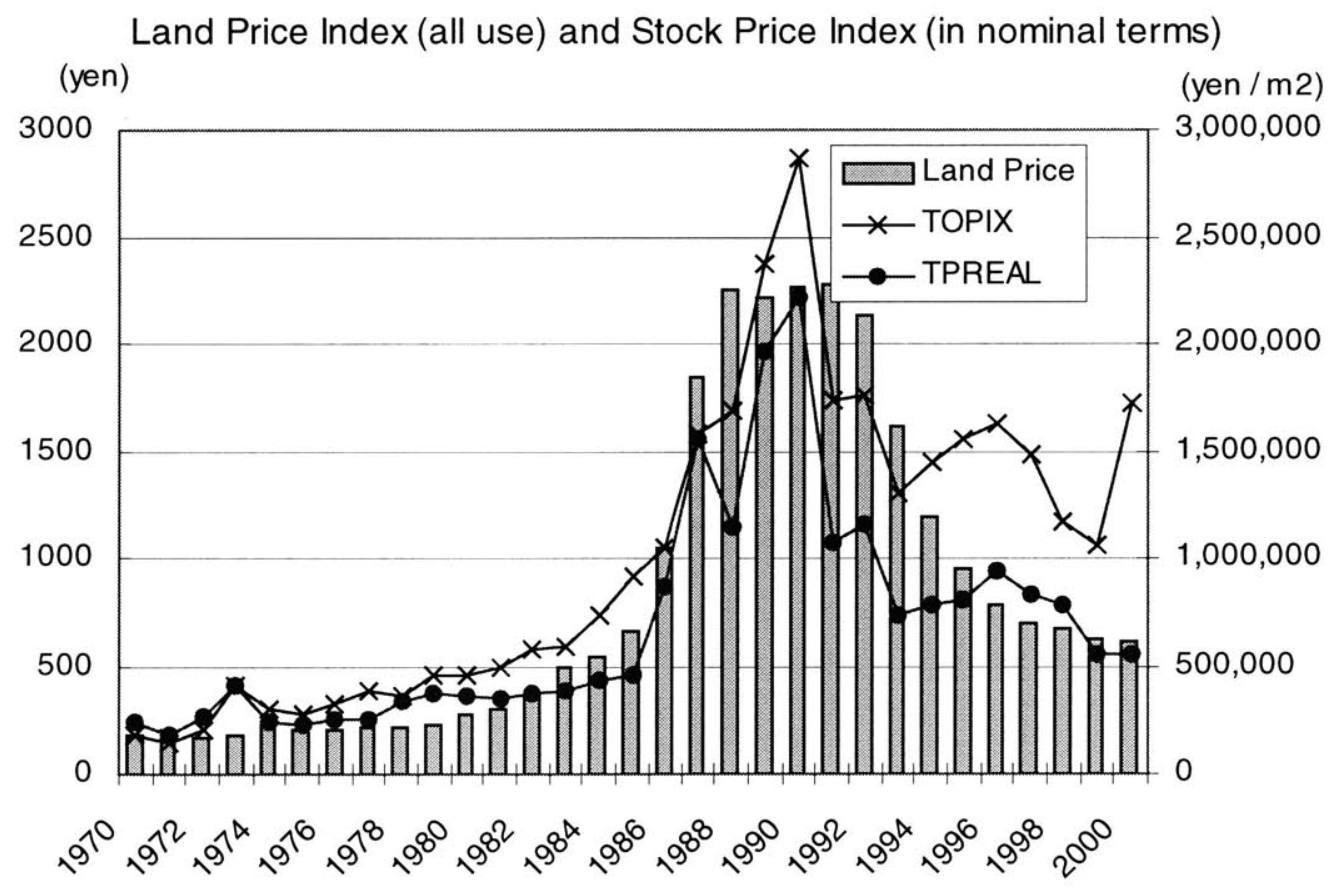

Figure 2-4: Land Price Index and Stock Price Index

${ }^{6}$ The correlation between prices of the TPREAL and those of TOPIX Index is higher than the correlation between the Land Price Index and the TPREAL Index 
(3) Housing Markets

From 1987 to 1990, when the land prices had risen extremely, the number of new houses constructed was 1.7 million per year in Japan; In Tokyo construction decreased to 200 thousand in 1989 and again in 1990 increased to 220 at the level of the year before. After the biggest drop in 1992, construction gradually increased against the background of low interest. This strange behavior is because the nominal interest rate seemed low and people who wanted to buy housing but could not afford it in the bubble era looked for housing in the last few years. However, the current inflation rate is very low, especially negative in real estate market, so the real rate is higher than the nominal rate. Land values are still declining and most real estate investors are suffering from latent loss. Although in 1996 before the consumption tax rose lastminute buyers created housing demand, construction has largely decreased afterward reflecting depression [Figure 2-5: Housing Starts]. In addition, many old residential

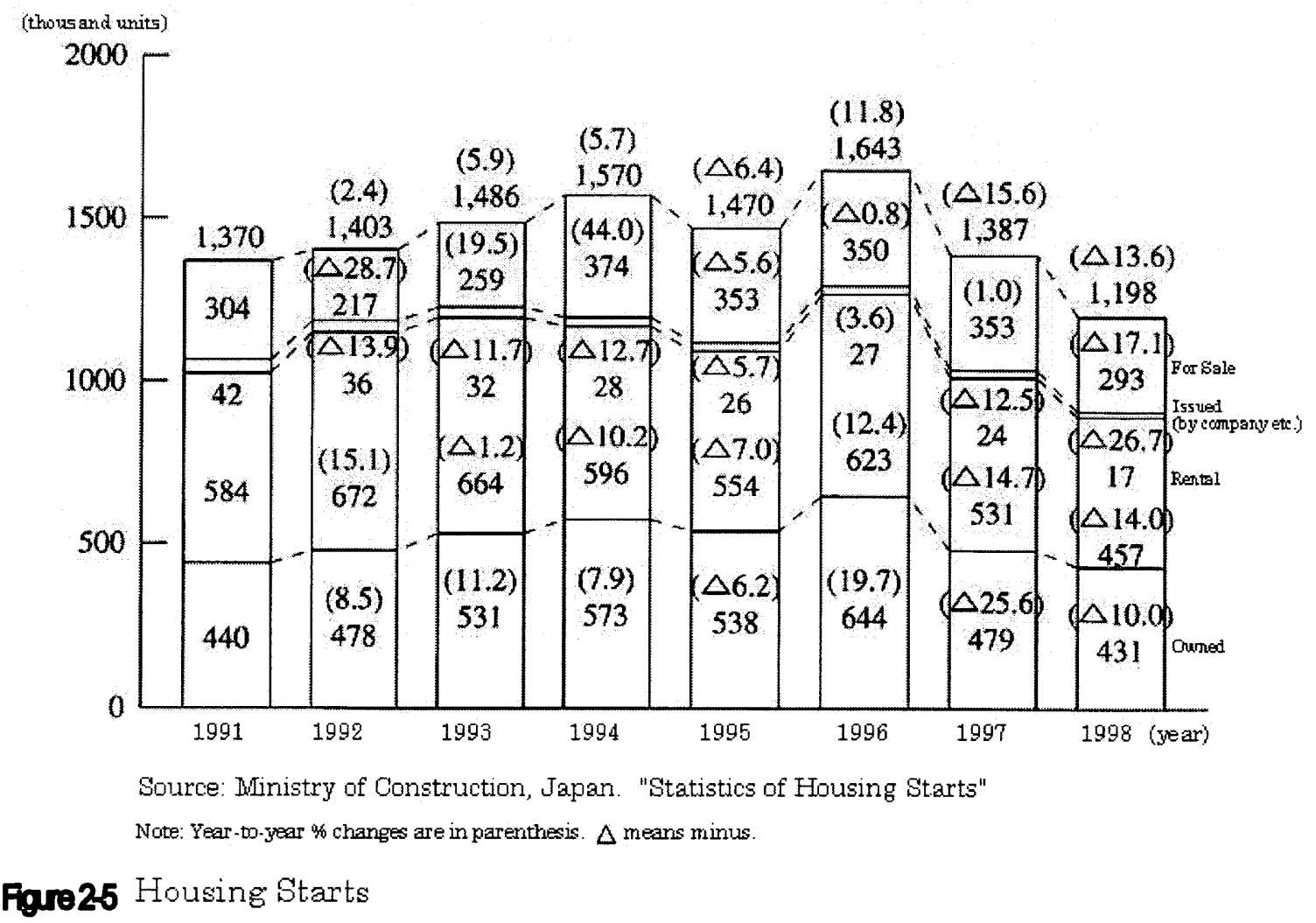


buildings and even new ones have reached a high vacancy rate, which has caused some developers go into bankruptcy.

\section{(4) Office Markets}

The construction of office floor space increased 71.1\% in 5 years from 1985 to 1990 . However, it decreased $49.6 \%$ in the next 5 years from 1991 to 1996 . In 1996 construction increased $21.0 \%$ against the consumption tax rise, since then it has again decreased [Figure 2-6: New Construction of Floor space of Office Buildings and Stores]. (Here an office is defined as a place for desk work or similar activities.)

The vacancy rate in Tokyo 23 Wards once reached the highest $9.6 \%$ in 1994 then gradually dropped to $4.7 \%$ in 1997 . In 1998 it again increased to $5.4 \%$. This occurred in major urban areas in Japan, which shows the office market is still struggling. Though the theory about the housing market says that the prices and vacancy rate is trade-off, the office rent has continued decreasing after the bubble and dropped $2.6 \%$ in Tokyo 23 Wards in 1998 [Figure 2-7: Vacancy Rates and Rents of Office buildings].

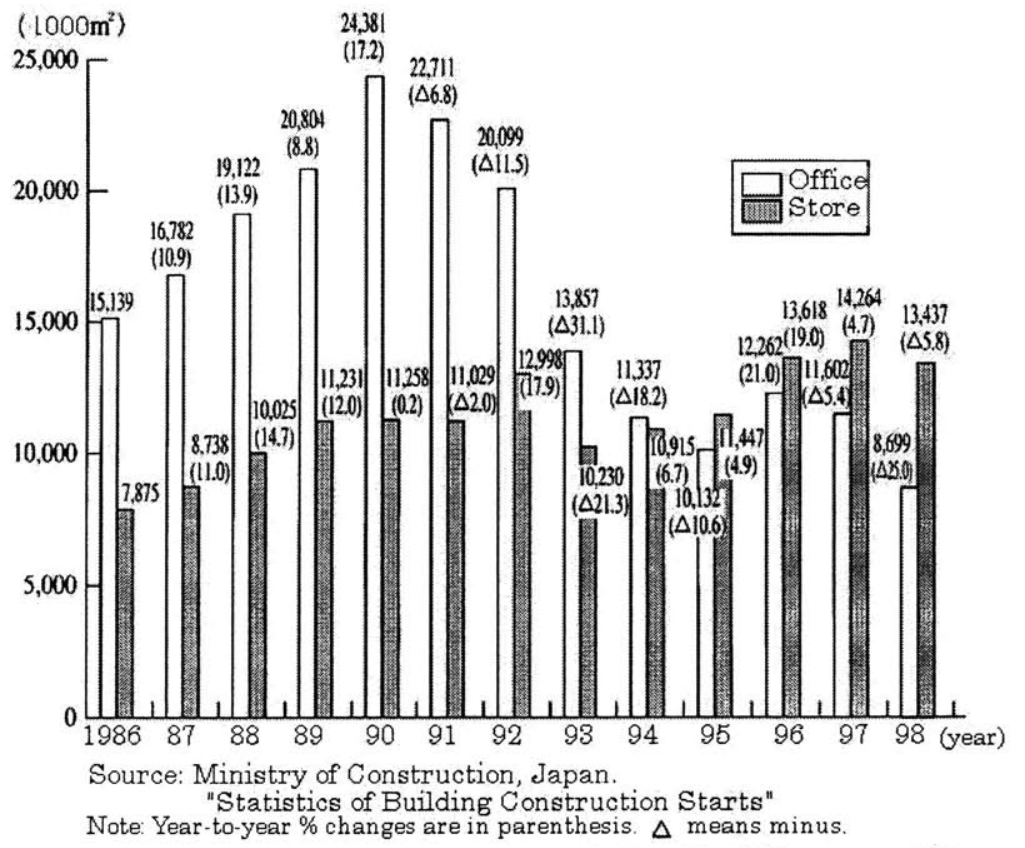

Fgre26 New Construction of Floor Space of Office Buildings and Stores 

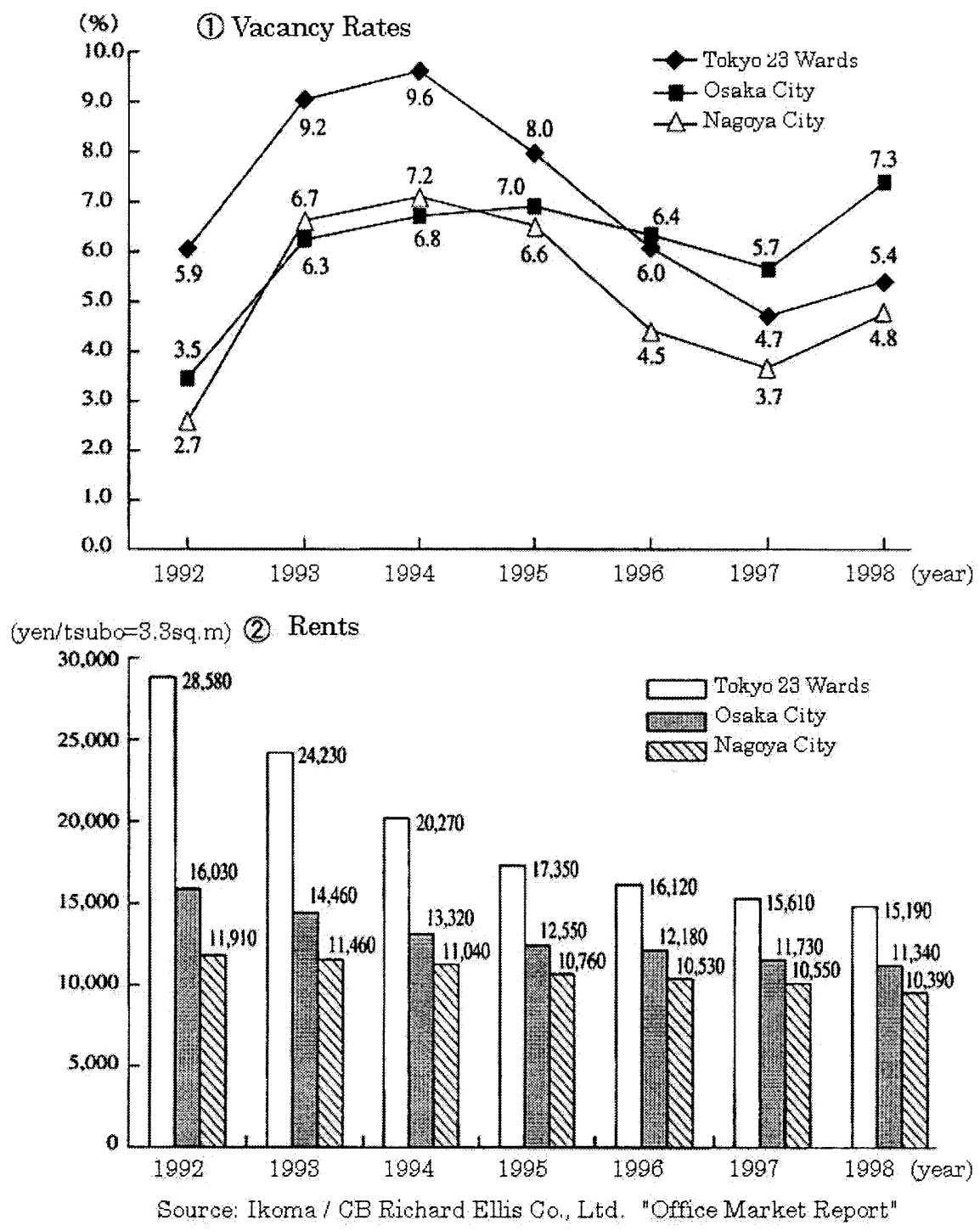

Fgre27 Vacancy Rates and Rents of Office Buildings

\section{Notes: The Land Price Index}

The Land Price Index is the Japanese government's set of benchmark land prices which are appraised by the Land Appraisal Committee of the National Land Agency as of January $1^{\text {st }}$ every year. These prices provide the most reliable benchmarks for ordinary transaction prices or acquisition prices for public projects. This nationwide survey has been conducted in the City Planning Areas of City Planning Law since 1970, 
though it was conducted only in metropolitan areas in the early years. The posted points are chosen in reference to their representativeness of the areas, moderation and stability of the prices $31,000(30,800)$ points were chosen from the whole Urban Planning Areas $98,552 \mathrm{~m}^{2}\left(98,202 \mathrm{~m}^{2}\right)$ in 2000 (data in parenthesis is in 1999). In Tokyo $2,651(2,917)$ locations, including $690(690)$ in commercial zones and 1,961 $(1,973)$ in residential zones were surveyed [Table2-1: The Number of Survey Points].

The prices are posted as "normal" unit land prices, that is, at the proper prices of marketable assets in a rational market for January $1^{\text {st }}$. The appraisers estimated prices by examining more than five surrounding transaction prices and calculate the values according to the prescribed chart, weighing on the transaction case method. If there are buildings or surface rights on the properties, the prices are calculated as if they were vacant lands. Individual attributes such as transportation or environment are expressed numerically in an undifferentiated way. This data contain not only prices and location (address) but also attributes of the lot such as lot size, zoning, street frontage, accessibility to major transportation, and current building property on it. These points are altered when their land use changes or the land is divided or absorbed. Although this substitution rate is recently relatively low (1 5\%) for each year, this lack of consistency in time-series data makes analyses on land prices difficult. 
Table 2-1: The Number of Survey Points Land Price Index

\begin{tabular}{|c|c|c|c|c|c|}
\hline & \multicolumn{4}{|c|}{ Central Tokyo } & $\begin{array}{r}3 \text { Wards } \\
\text { CBD }\end{array}$ \\
\hline 1983 & 16,975 & 638 & 331 & 75 & 23 \\
\hline 1984 & 16,975 & 1,363 & 763 & 185 & 64 \\
\hline $1985^{*}$ & 16,975 & 1,360 & 746 & 163 & 52 \\
\hline 1986 & 16,635 & 1,261 & 691 & 143 & 32 \\
\hline $1987^{*}$ & 16,635 & 1,013 & 458 & 115 & 48 \\
\hline 1988 & 16,820 & 1,173 & 752 & 183 & 73 \\
\hline 1989 & 16,840 & 1,482 & 845 & 209 & 77 \\
\hline 1990 & 16,865 & 1,463 & 841 & 206 & 78 \\
\hline 1991 & 16,892 & 1,480 & 843 & 214 & 73 \\
\hline 1992 & 17,115 & 1,491 & 856 & 221 & 78 \\
\hline 1993 & 20,555 & 1,497 & 860 & 229 & 83 \\
\hline 1994 & 26,000 & 1,969 & 1,127 & 304 & 108 \\
\hline 1995 & 30,000 & 2,365 & 1,352 & 361 & 129 \\
\hline 1996 & 30,000 & 2,624 & 1,491 & 396 & 144 \\
\hline 1997 & 30,300 & 2,576 & 1,472 & 395 & 144 \\
\hline 1998 & 30,600 & 2,917 & 1,493 & 402 & 149 \\
\hline 1999 & 30,800 & 2,917 & 1,490 & 397 & 148 \\
\hline 2000 & 31,000 & 2,651 & 1,513 & 410 & 152 \\
\hline
\end{tabular}

* Note: The Table includes compensated 8 missing data of 1985 and 12 


\section{Literature Review}

There are not many papers analyzing land prices empirically. First, the land prices are affected by numerous economic and other factors which are hard to capture in models. Second, the data on land prices are hard to obtain, and even if the data exist, they are often available for only single times.

\section{$<$ Land Price Models $>$}

Several papers try to capture land price movements by macro economic models. Land is regarded as one real asset and estimated considering financial and economic factors. Miyao (1993) examines the bubble of land prices using the discount factor method and concludes that stability is the key to recognizing the bubble from land price variations. Then he argues that the effects of land taxation could have a positive capitalization effect. Doi et al. (1994) develops an asset value imputation model which spatially and dynamically simulates land prices in the Tokyo Metropolitan Areas assuming location-specific attributes and the macro economic environment determin the prices. They also examine several combinations of land policies and the expected effect of the improvements. Colwell and Munneke (1999) provide strong empirical support for the degree of concavity within the Central Business District (CBD) is lower than in the rest of the urban area. They also argued that concavity may be the dominant pricing relationship throughout most urban areas and that there is some evidence of the presence of a convex price structure within the urban center. Hatta and Ohkawara (1993) presents a comparison of the land price structures in Tokyo and N.Y. They discussed the land price model from the view of commuting: models are set up in terms of demand and supply using "fatigue" as a commuting factor for the land price 


\section{Emprical Testing of Real Option-Pricing Models Using Land Price index in Japan}

instead of a commuting cost. They ignored the growth of land prices, which is very high in Japan, and only used single time data. In addition, they concluded that there was a positive relationship between commuting cost and land price by fixing the land price in the Central Business District (CBD), other researchers have claimed the opposite relationship. DiPasquale and Wheaton (1996) argued that a higher commuting cost would raise land price; that is, negative relationship. They fixed the city border and the land price at the edge of the city, explaining that the land price at the edge of the city should be equal to the agricultural land price, which seems more reasonable. These papers above focus on creating land price models and not dealing time-series data.

The other researchers analyze empirical data by time-series. McMillen (1996) presents locally weighted regression estimate for land values in Chicago by distance in each year. The results show that the monocentric city model represents land values through the early $19^{\text {th }}$ century but no longer explains it in 1960-1990. Thorsnes and McMillen (1998) use several estimate methods to analyze the relationship between land values and parcel size in a sample of 158 undeveloped parcels for 5 years adding yearspecific dummy variables. Their findings are that semiparametric estimates support a simple log-linear parametric relationship.

Few papers use the Land Price Index provided by the Japanese government. One reason is that not many survey points are continuously surveyed for a long time; in other words, very few long-term time-series data are available, although the survey has been conducted since 1970. In order to compensate for these non-continuous data in the Land Price Index, Ando et al. (1992) provided the missing data by regression models, created new time-series data in some survey points, and conducted space-time analysis 


\section{Empincal Testing of Real Option-Pricing Models Using Land Price Indexin Japan}

on land price variations in two Japanese Metropolitan areas, Tokyo and Osaka. The results show that a time lag exists between Tokyo and Osaka for experiencing the land price bubble.

\section{$<$ Land Price with Uncertainty>}

New concepts to capture land price movements assume stochastic process. Capozza and Helsley (1990) propose a model of an urban area with growth and uncertainty. They introduced stochastic processes of household income, rents and prices and assumed investors are risk-neutral. The findings are that uncertainty affects both land rents and land prices in equilibrium and that growth affects land prices but not the level of rents. The authors show that uncertainty delays the conversion of land from agricultural to urban use, imparts an option value to agricultural land, causes land at the boundary to sell for more than its opportunity cost in other uses, and reduces equilibrium city size. Fujita (1991) presents a rational expectations equilibrium (REE) model of urban spatial growth under uncertainty with an infinite horizon. His REE path of the urban land market is a function of the exogenous stochastic process of future population, transportation cost, and household income in the city. He also examined in detail the spatial and temporal structures of real-asset prices along the REE paths. 


\section{Overview of Theories}

\section{Real Options}

Dixit and Pindyck (1994) have explained investment decisions understandably in their book. They site that most investment decisions share three important characteristics. First, the investment is partially or completely irreversible. Second, there is uncertainty over the future rewards from the investment. Third, some flexibility about the timing of the investment usually exists. These three characteristics interact to determine the optimal decisions for any investor.

Within the neoclassical theory of investment, the net present value (NPV) theory, has not recognized the interaction between irreversibility, uncertainty, and the choice of timing. Real world investment seems less sensitive to changes in interest rate and tax policy, and much more sensitive to volatility and uncertainty over the economic environment. A growing body of literature has shown that the ability to delay an irreversible investment expenditure can profoundly affect the decision to invest.

Although most capital investment decisions are irreversible, they can be delayed while better information is sought. In addition, these decisions are made under the ongoing uncertainty of the economic environment. This situation is analogous to the theory of options in financial markets. A totally irreversible investment is exactly a call option. A call option gives the holder the right but not obligation to pay an exercise price for some specific period and in return receive an asset that has some value. To be specific, if the time of exercise is flexible at some future time of its choosing during the time period, it is an American call option. This option to invest is valuable because the future value of the asset obtained by investing is uncertain. If the firm makes an irreversible investment, exercises its option to invest, it may give up an opportunity of 


\section{Emprical Testing of Real Option-Pricing Models Using Land Price Index in Japan}

more desirable timing of investment. This lost option value is an opportunity cost that must be included as part of the cost of the investment. This opportunity cost is highly sensitive to uncertainty over the future value of the project. The new view of investment opportunities as options has shown that the traditional NPV rule can give very wrong answers unless all relevant option values are included in the NPV. Note that if choices are investing now or never, the standard NPV rule applies because there is no option to wait years.

\section{Stochastic Process}

A stochastic process is a variable that evolves over time in a way that is at least in part random. A Wiener process, a Brownian motion, is a continuous-time stochastic process with three properties: 1) A Markov process; that is, probability distribution for all future values of the process depends only on its current value and is not affected by past values of the process or by anything other than current information, 2) independent increments, and 3) normal distribution of changes in the process over any finite interval. Note that Brownian motion is the limit $\Delta t->0$ of a random walk and its variance grows linearly with the time horizon.

Geometric Brownian motion is frequently used to model securities prices as well as interest rates, and other economic and financial variables.

$d V=\alpha V d t+\sigma V d z$

V: project value

$\alpha$ : expected rate of return, drift rate

$\sigma$ : volatility of the asset price, standard deviation

$\mathrm{dz}$ : the increment of a Wiener process 
The variable $\mathrm{dV}$ is the change in the asset price, $\mathrm{V}$, in the limit of interval time, $\mathrm{dt}$ : The term $\alpha \mathrm{Vdt}$ is the expected price and $\sigma \mathrm{Vdz}$ is the stochastic component.

The real option theory is based on assumption prices are stochastic. It is widely known that changes in stock prices are lognormally distributed and follow Geometric Brownian motion. As real estate is also a financial asset and often compared to stocks, changes in real estate prices also follow the stochastic process.

\section{Characteristics of the Option to Invest}

The investment decision is made by comparison between the current value of the asset, $\mathrm{V}_{0}$, and its total cost, the investment cost plus the value of the option to invest, I

$+\mathrm{F}_{0}$. If $\mathrm{V}_{0}<\mathrm{I}+\mathrm{F}_{0}$, not invest. If $\mathrm{V}_{0}>\mathrm{I}+\mathrm{F}_{0}$, invest now, $\mathrm{t}=0$. Between these two situations, wait and see whether better information comes. Note that waiting means giving up revenue in coming years.

The decision to invest or to wait depends on the parameters that specify the model, most importantly the extent of the uncertainty and the discount rate. In other words, uncertainty and growth can create a value to waiting and affect investment timing. The uncertainty determines the downside risk avoided by waiting for better information, and the discount rate measures the relative importance of the future versus the present:

$$
1+\mathrm{r}=(\text { Future Value }) /(\text { Present Value })
$$

In the contingent claims approach, the required rate of return on the asset was derived as an implication of the overall equilibrium in capital markets. Only the riskless rate of return, $\mathrm{r}_{\mathrm{f}}$, is taken to be exogenous. The opportunity cost of capital should equal the risk-adjusted expected return which the investor could have earned on 
other investment opportunities with comparable risk characteristics; therefore, the rate of return is risk-free interest rate plus risk premium.

In order to value a new asset, replication of its return and risk characteristics through a portfolio of existing traded assets is made. The implication here is to create a risk-neutral portfolio (Cox and Ross(1976)), that is, its value next year is independent of whether the price of the asset goes up or down. The rate of return from holding the asset must be equal to the riskless return.

According to the capital asset pricing model, CAPM, the expected return satisfies;

$\mu=\alpha+\delta=\mathrm{r}_{\mathrm{f}}+\mathrm{RP}=\mathrm{r}_{\mathrm{f}}+\beta\left(\mathrm{r}_{\mathrm{m}}-\mathrm{r}_{\mathrm{f}}\right)=\mathrm{r}_{\mathrm{f}}+\sigma_{\mathrm{PM}} / \sigma_{\mathrm{M}} 2 *\left(\mathrm{r}_{\mathrm{m}}-\mathrm{r}_{\mathrm{f}}\right)$

$\mu$ : risk-adjusted expected rate of return

$\alpha:$ growth rate of return

$\delta$ : dividend rate of return

$\mathrm{r}_{\mathrm{f}}$ : risk-free rate of return

$\mathrm{RP}$ : risk premium

$\sigma_{\mathrm{PM}}$ : covariance with the asset with market portfolio

$\sigma_{M}^{2}$ : variance of market portfolio assumed to be fxed in this paper)

$\mathrm{r}_{\mathrm{m}}$ : market return (ascumed to be fired in the paper)

Note that the condition is that the risk-adjusted interest rate, $\mu$, is larger than the expected growth rate, $\alpha$, $(\mu>\alpha$ or $\delta>0)$, because investment would never occur if expected growth rate, $\alpha$, is larger than the risk-adjusted interest rate.

Investors want to maximize the expected present value:

$\mathrm{F}(\mathrm{V})=\max \mathrm{E}\left[\left(\mathrm{V}_{\mathrm{T}}-\mathrm{I}\right) \mathrm{e}^{-\mu_{\mathrm{T}}}\right]$

This $F(V)$ is the value of investment opportunity, the value of firm's option to invest. This is calculated by creating risk-neutral portfolio based on contingent claims 


\section{Emprical Testing of Real Option-Priaing Models Using Land Price Index in tapan}

analysis (Dixit and Pindyck (1994)). F(V) is given by the following incorporated variables; risk-free interest rate, $\mathrm{r}_{\mathrm{f}}$, dividend rate, $\delta$, uncertainty over the asset value $\mathrm{V}$, $\sigma$, covariance with the asset with market portfolio, $\sigma_{\mathrm{PM}}$, and input cost I7. FFigure $3-1$ :

\section{Value of Investment Opportunity].}

$\delta$ is an opportunity cost of delaying construction of the project and instead keeping the option to invest alive. In addition, if the dividend rate is $0, \delta=0$, analogous to a call option with no dividend, which would always be held to maturity and never be exercised prematurely, no opportunity cost of keeping the option alive exists, and investment would never occur ${ }^{8}$. If $\delta$ is very large, the opportunity cost of waiting is very large and the value of option will be very small.

A low interest rate makes the future generally more important relative to the present; therefore, it increases the opportunity cost of exercising the option to invest. However, a lower rate also increases the dividend rate, which lowers the option value.

$$
\begin{aligned}
& { }^{7} F(V)=A V^{\beta} \quad \text { s.t. } \mathrm{F}(0)=0 \\
& A=\frac{(\beta-1)^{\beta-1}}{\beta^{\beta} I^{\beta-1}} \quad \beta=\frac{1}{2}-\frac{\left(r_{f}-\delta\right)}{\sigma^{2}}+\sqrt{\left[\frac{\left(r_{f}-\delta\right)}{\sigma^{2}}-\frac{1}{2}\right]+\frac{2 r}{\sigma^{2}}}
\end{aligned}
$$

(Dixit and Pindyck (1994))

8 The present value of the investment is determined by the timing of the commitment made and will tend to lag. This lag in value is similar to the drain in price by a continuous dividend stream and provides an incentive for "early exercise". (see. Ingersoll and Ross (1992)) 

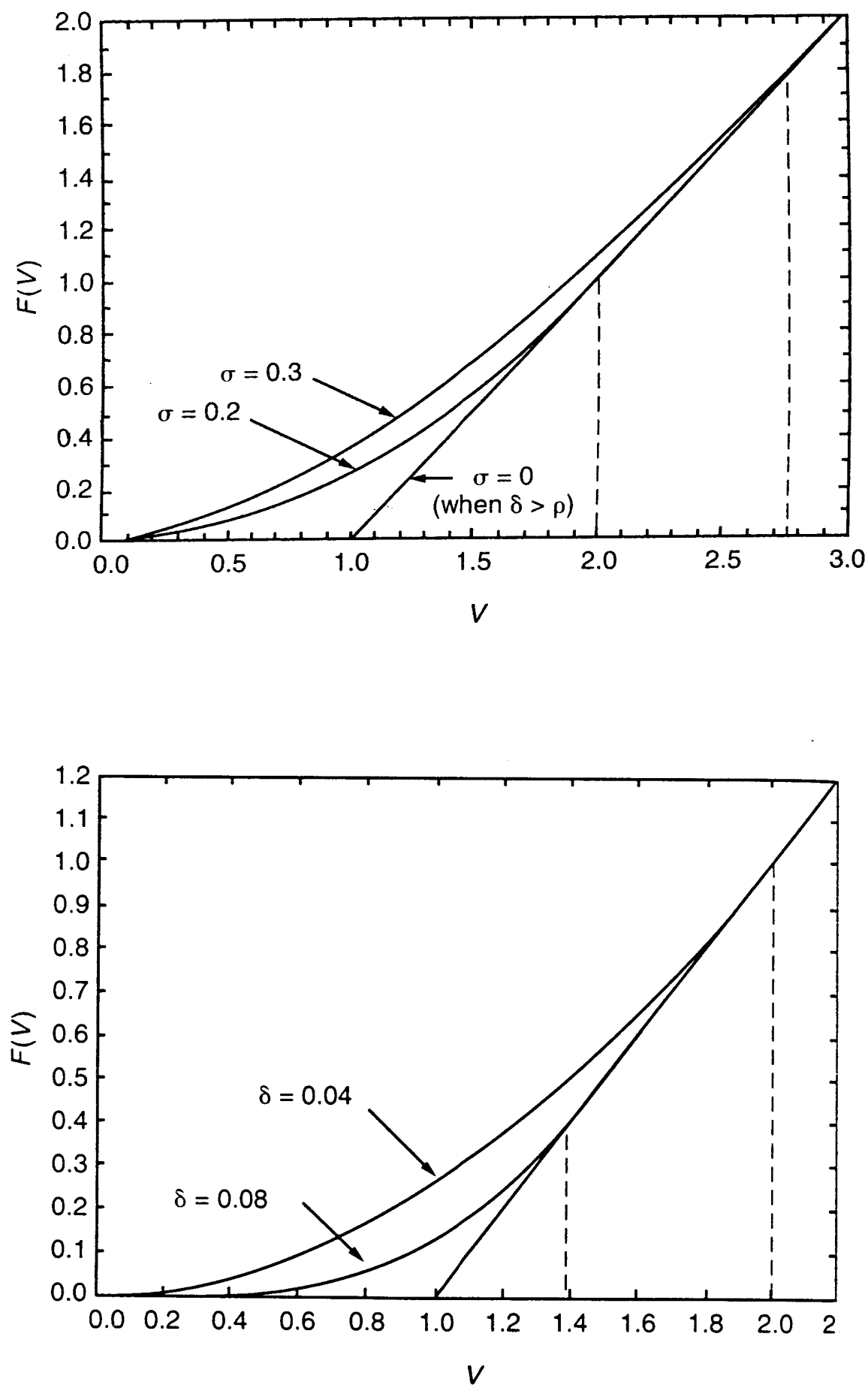

Figure 3-1: Value of Investment Opportunity,

"Investment under Uncertainty" Dixit and Pindyck (1994) pp.154, 156 
The real options approach suggests that various sources of uncertainty about future profits, such as fluctuation in asset prices, input costs, tax and regulatory policies, have much more important effects on investment than the interest rate. McDonald, R. \& Siegel, D (1986) analyzes the optimal timing of investment. They assume that the project value and the investment cost are stochastic. Their simulations show that the option value can be significant focusing the ratio of the two.

1) Cost of the Investment... I

The investment decision is made by seeing whether payoff from investing is as much as the sum of investment cost and an opportunity cost of investing. It can be easily imagined that the smaller cost of investment, the larger the value of the investment opportunity, therefore, the more likely an investment occurs.

\section{2) Price... P}

The return is the capital gain of holding the asset minus any payments. Note that it is analogous to selling short a dividend-paying stock; the short position requires payment of dividend. A higher probability of a price increase decreases the critical value of the initial price for immediate investment. The value of the investment option is a convex function of the initial price. In addition, this critical value depends only on the size of the downward move and its probability.

\section{3) Uncertainty over Price}

An increase in uncertainty raises the value of the option to invest, because larger uncertainty increases the upside potential payoff from the option, leaving downside payoff unchanged at zero by not exercising the option. Therefore, as the value of option 
gets larger, the opportunity cost of investing now rather than waiting is larger, that is, greater is an incentive to wait. This paper focuses on this uncertainty.

\section{4) Uncertainty over Cost}

Like the uncertainty over the price, the uncertainty over the cost of a project creates an incentive to wait. However, if this uncertainty can be resolved by starting to invest, for example, the cost appears for coming years, this uncertainty lowers the hurdle rate for a project. This paper treats construction costs as exogenous.

\section{5) Uncertainty over Interest Rates}

The uncertainty over the future interest rate increases the expected value of the project. This is an implication of Jensen's Inequality when the price function is convex of the interest rate. Nonetheless, uncertainty over future interest rates can still lead to delays, because the interest fluctuation creates a value of waiting, which has often the stronger effect on payoff. Ingersoll and Ross (1992) show that accepting the positive net present value (NPV) is generally wrong because a project with an ability to be delayed could compete with itself as postponed. In an uncertain economy, most investment projects have option values so that the rate of aggregate investment will depend on both the level of real interest rate and the degree of interest-rate uncertainty. Therefore, with uncertain interest rates, no investment should be undertaken until the interest return is substantially lower than its breakeven rate (the rate where the NPV is zero). An increase in uncertainty in the interest rate lowers the acceptance interest rate below its breakeven rate. Note that interest rates are exogenous in this paper. 


\section{Application to Real Estate Price}

Titman (1985) first applied the real option theory to real estate prices. In his paper he shows that the value of vacant developable land is a call option. He applies the Black-Scholes option pricing method and shows that the vacant land becomes more valuable as uncertainty on future prices increases.

In the application of the real option theory to real estate, investment means building development and the underlying asset is the (future) built property. Real estate development is usually irreversible: construction cost is at least partially sunk and the investment is totally irreversible once a building asset has been developed. In addition, development can be delayed upon the investor's decision. As seen above, an investment with these characteristics has an option value. Note that the underlying asset pays rents as dividends in the form of the net cash flow from the built property once it is completed. In this sense, land is an American option on an underlying asset paying dividends.

In this case, the value of investment opportunity, $\mathrm{F}(\mathrm{V})$ is land price, $\mathrm{L}$, and $\mathrm{V}$ is the value of real estate assets including its land value and the (future) built property. As seen above, $F(V)$ is given by the following incorporated variables: risk-free interest rate, $\mathrm{r}_{\mathrm{f}}$, dividend rate, $\delta$, uncertainty over the asset value $\mathrm{V}, \sigma$, covariance of the asset with market portfolio, $\sigma_{\mathrm{PM}}$, and input cost I.

This paper uses multiple regression models whose the dependent variable is land price and independent variables are time-series following variables and cross-sectional amenity variables, which are reviewed in later sections. Note that land prices are provided by their addresses listed, however, the same survey points were not always chosen in the following years; therefore this data set is not the panel data. 


\section{Literature Review}

Various topics on real estate are based on the option pricing theory. Trigeorgis (1996) classifies several real estate categories in his book. Here, only papers related to real estate development are quoted.

\section{a) Real Estate Price}

The first work on the option pricing model applying to real estate prices was done by Titman (1985). He develops models pricing vacant lots in urban areas. He demonstrates binary option price models and shows that increased uncertainty leads to a decrease in building activity in the current period. Williams (1991) computes optimal exercise prices for development or abandonment of real estate given that the owner can determine the density or scale of the development and both the operating revenues from the developed property and its cost of development evolve stochastically through time. He shows that this stochastic evolution affects the optimal date and density of development, the optimal date of abandonment, and the resulting market values of the developed and undeveloped properties.

Williams (1993) analyzes equilibrium on real assets at the exercise of development options considering the aggregate effects of the exercise. His assumption is that demand produced by real assets has a finite elasticity, supply of the option is limited, developers have finite capacities on development, and developers are not perfectly competitive. Then he shows that any developer will build at the maximum feasible rate whenever income rises above a critical value. Grenadier (1996) develops an equilibrium framework for strategic option exercise games focusing on the timing of real estate development and provides a rational foundation of overbuilding in real estate markets. 


\section{Empincal Testing of Real Option-Pricing Models Using Land Price Index in Japan}

His model demonstrates that development options might be exercised sequentially or simultaneously and provides a rational foundation for building booms.

Lentz and Tse (1995) apply option pricing to examine the ways that the presence of hazardous materials affects real estate value. The option in this paper is to remove the hazardous materials and redevelop the property given three possible timing strategies: do it at separate times, do it at once, or do nothing. The results show that the loss in property value increases if property owners are not permitted to make optimal decisions and suggest that the option value foregone can be used as a measure of the cost of regulation.

Riddiough (1997) focuses on the economic consequences of restricting development rights on land value and development activity. He shows that investors rationally hold land undeveloped for a while by reflecting price uncertainty and recognizing an owner's ability to defer investment decisions. The finding is that land value is affected by regulatory on development flexibility and ex-ante compensation requirements for interim takings.

\section{b) Lease contract}

Capozza and Sick (1991) focus on redevelopment option and outline a financial model for valuing leased property, considering the value of the option to upgrade or redevelop. They show that the discount of leased fee-simple properties can be better explained by the value of redevelopment option. Grenadier (1995) developed a unified framework for pricing various leasing contracts. He focused on the term structure during the lease term and changing rent structure. An economic uncertainty and competitive interaction of firms can be seen. An empirical approach was done by 


\section{Empincal Testing of Real Option-Pricing Models Using Land Price Index in Japen}

Buetow and Albert (1998), who analyzed leases and rental agreements granting an option: an option to renew a lease and an option to purchase the leased space. Using rent office space data from the Market History Reports of the National Real Estate Index (NREI), he estimate the value of embedded option in lease contracts. A similar study was done by Hendershott and Ward (2000), who show that the value of a shopping center is the present value of the expected cash flow plus the value of optionlike features, which can have positive or negative values. The conclusion is that the option value is substantial when volatility of sales is high and that with low expected drift in sales, a low threshold raises the option value.

\section{c) Land Use}

Childs et al. (1995) examine the potential for mixing uses and for redevelopment impact in property value. The results show that operational flexibility by possibility of mixed-uses on a single site increases property value and affects the timing of initial land development considering irreversibility and delay. In addition, they present an idea that redevelopment options may have significant value and impact the initial development decision as well. Geltner et al. (1996) examined the effect of land use choice on speculative land prices and development timing. They estimate the hurdle values of two types of land use and option values. The results show that multiple-use zoning may add an over $40 \%$ premium to land value.

\section{(d) Empirical Testing of Real Estate Price}

Little empirical work on the relationship between uncertainty and investment has been done. Paddock et al. (1988) apply option valuation theory to valuing leases for 
offshore petroleum, including actual tracts data in the federal lease sale. They show the necessity of combining option pricing techniques with a model of equilibrium in the market for underlying asset. Leahy and Whited (1996), though not studying real estate, analyze the relationship between uncertainty and investment by cross-section and time-series, using panel data on individual firms' investment environment. Their results indicate that an increase in uncertainty decreases investment, primarily through its effect on Tobin's q. In addition, their results support the convexity of the marginal revenue product of capital. Holland et al. (1998) examine the role of uncertainty in investment using aggregate commercial real estate data, NCREIF and equity REITs. They estimate the model is solving simultaneous equations of commercial real estate market equilibrium, demand and supply, which include uncertainty terms. The two different measures of total uncertainty are employed; the implied volatility (a forward-looking measure) and the standard deviation of daily return. The authors also considered the lags of time-series variables. The results show that option-based models can better explain investment; irreversibility and delay have important roles in investors' decisions. Yoshida (1999) applied their models in examining the validity of the option-based investment model in the decision making of commercial real estate development, using aggregate real estate and economic data in Japan. He specified a structure model and incorporated the interactions between supply and demand in real estate markets. The results supported the option-based investment model in both demand and supply and concluded that various kinds of real options must be incorporated in investment and economic models.

Quigg (1993) examined the empirical predictions of real option-pricing models using about 3,000 urban land transaction data in each developed property and 
unimproved land parcel within the city of Seattle. She presents hedonic price functions of land value classified by years and zoning categories. The results show that market prices reflect a premium for the development option to wait at a mean of $6 \%$ of the land value and that the option model has explanatory power for predicting transaction prices.

\section{Hedonic Models}

$<$ Hedonic Model on Real Estate $>$

Orthodox methods to estimate prices of real estate by cross-section use hedonic models. Many models define real estate price as the dependent variable and various environmental qualities as independent variables. The method allows researchers to estimate the functions and evaluate different environmental quality (Hidano (1997)). However, few reasonably high-quality data on the environment are available and the qualities are unobserbable in most cases.

Kanemoto (1992) applies hedonic models for benefit estimation in real estate prices using two-region model based on the fact that the difference between the prices reflects the difference between the environment. He concluded that the benefit estimation using the difference from cross-section is more reliable than time-series analysis. Nakamura (1992) employs a bid rent function and a market price function and estimates housing prices. DiPasquale \& Wheaton (1996) introduced several hedonic models to estimate housing prices in the Boston metropolitan area using American Housing Survey (AHS) data. The result is that more bedrooms, bathrooms, and the presence of a garage all increase the price of the home and that the price declines if the unit is located in the central city. 


\section{Empincal Testing of Real Option-Pricing Models Using Land Price Index in Japan}

Other researchers focus on time-series variation in real estate prices. Yai et al. (1992) proposes ordinal hedonic land price models and LISREL models using the Land Price Index in Yokohama City, Japan. They classified price factors in location and lot characteristics and transportation demand and examined external changes on transportation. Mills and Simenauer (1996) uses a national housing price data set, the House Financing Transaction Database by the National Association of Realtors, for the years 1986-92 and estimates log-linear hedonic regression with intercept permitted to vary by year and region. Their results are that lot size is of no practical consequence, rather, suburban location adds $11.5 \%$ to dwelling value, and that characteristics improvements had increased more than half of home price. Clapp and Giaccotto (1998) analyze the hedonic repeated-emasures (HRM) model and the standard repeat-sales model.

\section{Pool Data Analysis}

Since the land price index is surveyed once a year, time-series data is limited. On the other hand, there are many survey points, numbers of cross-sectional data, in each year. In the previous section, hedonic models are estimated by each year then the coefficients are compared by the year. However, the model cannot account for any economic environmental changes surrounding real estate markets over time. (Pindyck

In principle, the use of panel data can sort out economic effects that cannot be distinguished with the use of either cross-sectional or time-series data alone. The advantages of this method are two: first, increased data points, which generates additional degrees of freedom, and second, incorporating information relating to both 
cross-section and time-series, which can diminish problems caused by omitted variables.

However, the use of panel data adds a new dimension of difficult model specification problems; the disturbance term is likely to consist of time-series-related disturbances, cross-section disturbances, and a combination of both. If these components can be separated out, the causes of land price variations can be distinguished.

The Fixed-effects Model introduces dummy variables that allow the intercept term to vary over time and over cross-sectional unit. This is based on assumption that the combined error component equals zero. However, the problem is that the use of dummy variables does not directly identify causes over time and cross-section and reduces the degree of freedom. In part for this reason, researchers often specify models that include only cross-sectional fixed effects. On the other hand, when the combined error component becomes arbitrarily large, the model approximates the ordinary least squares pooled data model.

Leahy and Whited (1996) used panel data on individual firms' investment environments to analyze the relationship between uncertainty and investment by crosssection and time-series. Their results separate out characteristics of individual firms and their capital structure, which indicate that an increase in uncertainty decreases investment. Quigg (1993) does not use panel data; instead, she analyzes hedonic price functions of land value in each group of the city using dummy variables of the year when the property was sold

This paper analyzes the land price index by incorporating cross-sectional and timeseries information in one model. The pool data in this study are not panel data; that is, 
the survey points are different in each year. However, this analysis can be useful because it allows the sorting out of economic effects that cannot be distinguished with the use of either cross-sectional or time-series data. 


\section{Model and Data Specification}

\section{Hedonic Models}

As a first step in analyzing land prices, this paper analyzes lot attributes which may determine the land prices. Then, this research examines the way they have changed over time and their differences by sub-regions. A number of lot attributes are provided in numerically or nominally by the Land Price Index for each survey point with land prices such as size, shape, width, depth, building structure, the direction and width of the front street, maximum available floor area ratio (FAR), zoning, and distance from the closest train station. Among them, the variables in the following section are considered to have an effect on land prices and employed in the models. These variables can be classified in two categories: lot characteristics and location characteristics.

The model examines land prices from the view of time-series (1983 to 2000) and cross-section (wards).

$$
\left.\ln L_{i t}=f_{t} \text { (amenity variables }{ }_{i}\right)
$$

\section{Data}

*Dependent Variable [Table 4-1: Model Description]

L: land price

Log of land price provided by the Land Price Index converted in real terms by Gross Domestic Expenditure (GDE) deflator by the Economic Planning Agency

\section{*Independent Variables}

amenity variables 


\section{Table 4-1: Model Description}

$\mathrm{L}_{\text {it }}=\mathrm{f}(\mathrm{P}, \mathrm{K}, \mathrm{i}, \mathrm{y}, \sigma \rho \mathrm{M}, \sigma, \mathrm{u}$, amenity variables $)$

Economic Variables (aggregate, time-series)

\begin{tabular}{|c|c|c|c|}
\hline variables & & definition & predicted signs \\
\hline $\mathrm{L}_{\mathrm{it}}$ & land price & $\begin{array}{l}\text { Log of Land Price Index in real terms: log } \\
\left(y e n / \mathrm{m}^{2}\right)\end{array}$ & \\
\hline$P_{t}$ & built asset price & $\begin{array}{l}\text { Log of TPREAL in real terms (Stock Price Index } \\
\text { for real estate industry): log (yen) }\end{array}$ & + \\
\hline $\mathrm{K}_{\mathrm{t}}$ & construction cost & Log of Construction Cost Deflator in real terms & - \\
\hline$i_{t}$ & risk-free interest rate & $\begin{array}{l}\text { Japanese Gov. Bond Yield in real terms } \\
=(1+\text { Tbill }) /(1+\text { current infl })-1: \%\end{array}$ & - \\
\hline$y_{t}$ & rent yield rate & $\begin{array}{l}\text { MTB-IKOMA Real Estate Investment Index yield } \\
\text { rate of return in real terms : \% }\end{array}$ & - \\
\hline$\sigma_{\rho \mathrm{Mt}}$ & $\begin{array}{l}\text { systematic risk associated with owing } \\
\text { developed real estate assets }\end{array}$ & $\begin{array}{l}\text { Covariance of daily changes of TPREAL and } \\
\text { TOPIX in nominal terms }\end{array}$ & - \\
\hline$\sigma_{\mathrm{t}}$ & $\begin{array}{l}\text { total uncertainty with respect to built } \\
\text { asset return }\end{array}$ & Sandard Deviation of daily changes of TPREAL & + \\
\hline$u_{t}$ & hedonic residual & $\begin{array}{l}\text { proportional to residual of hedonic models in each } \\
\text { year } \quad=1 \text { - adjusted } R_{t}{ }^{2}\end{array}$ & - \\
\hline
\end{tabular}

Amenity Variables (Dis-aggregate, cross-sectional)

Lot characteristics

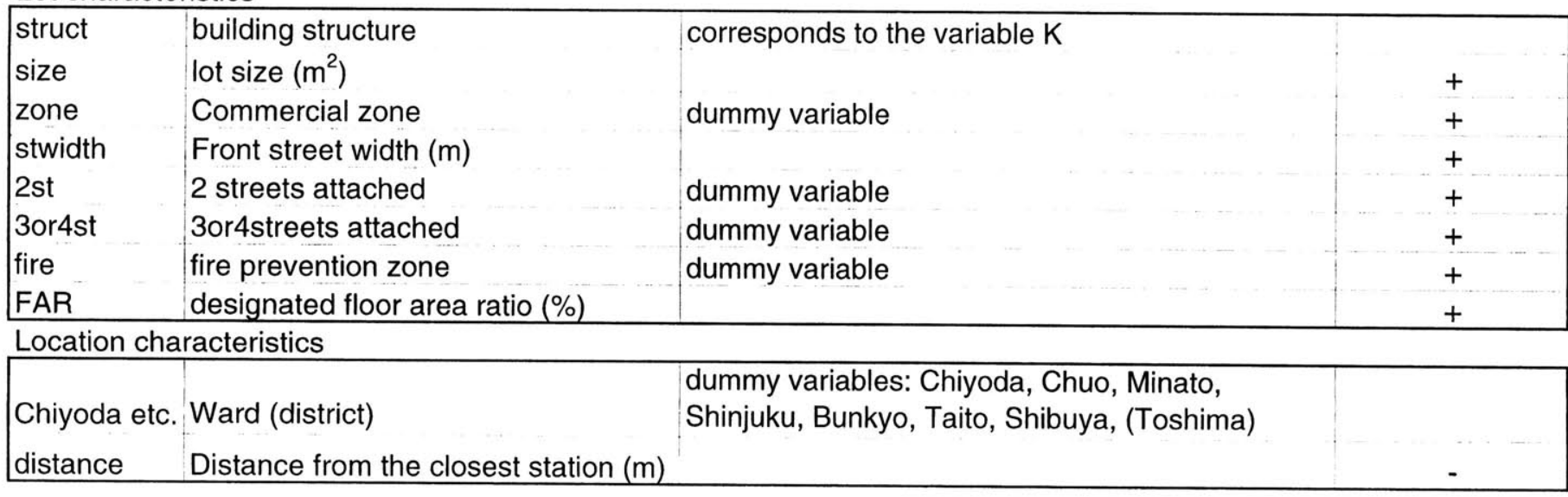


Among the data provided by the Land Price Index for each survey point, the following variables have significant effect on land prices. These variables can be classified in two categories; lot characteristics and location characteristics.

$<$ lot characteristics $>$

a. size .. lot size

There are several papers which analyzed the relationship between land values and parcel size. Brownstone and De Vany (1991) claim that subdivision costs lead to concave land value functions. Colwell and Sirmans (1993) suggest that assembling small parcels may be costly, producing a convex function over small parcel size. They argue that a land value function that is first convex and later concave in parcel size. Quigg (1993) used log of the lot size to log of the property price in hedonic functions. Thorsnes and McMillen (1998) found out that semiparametric estimates support a simple log-linear parametric relationship. Colwell and Munneke (1999) provides strong empirical support that the degree of concavity within the Central Business District $(\mathrm{CBD})$ is lower than in the rest of the urban area. They also argued that concavity may be the dominant pricing relationship throughout most urban areas and there is some evidence of the presence of a convex price structure within the urban center.

Here I adopt linear relationship assuming that the bigger lot is considered to have higher development potential, which makes lands more valuable.

b. zone ... commercial zone dummy

If the lot is designated as a commercial zone, the variable takes 1 , and 0 if residential zone. A lot in a commercial zone is more expensive than in a residential 
zone.

Kwong and Leung (2000) present that the commercial property (office) prices are more volatile than residential ones using endogeneous determination prices. In addition, floor area ratio (FAR) is higher in commercial zones than in residential zones; therefore, the correlation between the variables of zone and of FAR is very high, which may cause large variance of the estimates.

c. stwidth ... front street width

The wider street width is considered to be valuable and have higher development potential.

d. 2st ... dummy; two streets attached to the lot

If the lot is attached to two streets, the variable takes 1 , and 0 otherwise and regardless of which side of the lot the second road attached, side or back.

The lot attached to two streets is considered to be valuable and have higher development potential.

e. 3or4st ... dummy; three or four streets attached to the lot

If the lot is attached to three or four streets, the variable takes 1 , and 0 otherwise.

The lot attached to three or four streets is considered to be more valuable and have higher development potential.

f. fire ... fire prevention zone dummy

If the lot is designated in fire prevention zone, the variable takes 1 , and 0 
otherwise.

The lot in fire prevention zone is considered to be valuable because central Tokyo is crowded and vulnerable to fire.

g. far ... floor area ratio (FAR: floor space/ lot size \%)

The lot with higher FAR is more valuable and has higher development potential. Again, FAR is designated to be high in commercial zones so that this FAR variable and the commercial zone dummy have a higher correlation, which may cause large variance of the estimates. The FAR variable has very strong explanatory power to estimate land prices.

The following variables were tried in models with variables above and later omitted for the reason below.

h. irregularity in lot shape

If the lot has an irregular shape including a trapezoid, the variable takes 1 , and 0 otherwise

The irregularly shaped lot is considered to be less valuable. However, the result is opposite, the sign of the coefficient is positive. The reason may be the limited number of lots with irregular shapes.

i. lot width ... the length of the lot attached to the street.

j. lot depth ... the length of the lot perpendicular to the street.

The above two variables are not significant. In addition, the ratio of width to depth was included model, however, it was not significant. Not that the both variables affect 
the lot size.

1. the number of floors of the building on the lot

$\mathrm{m}$ : the number of floors of the building on the lot

Both of the two are significant and have positive coefficients. However, they are highly correlated to FAR; hence, they were omitted from further analysis.

<location characteristics $>$

Chiyoda etc. ... the ward dummy

If the lot is located in the ward, the dummy variable is 1 .

The chosen Tokyo 8 wards locate in central Tokyo and also contain main business areas. Chiyoda, Chuo, and Minato are central business district (CBD) of Tokyo, called Tokyo Central 3 Wards. They are highly commercialized areas and headquarters of most leading companies locate there. Shinjuku and Shibuya are subcenters of Tokyo lying west side of Tokyo Central 3 wards. They are popular for both business and residential areas. Note that west side areas of Tokyo have been more newly developed and land prices are also higher than those of east side areas of Tokyo. Bunkyo is more popular for residential rather than business areas. As it locates in north of Chiyoda ward, it has an inflow of companies which cannot locate in Chuo. Taito is old downtown locates in east side of Tokyo and used to locate retail industries. Toshima locates in north west side of Tokyo and is not as popular as other 7 wards.

B. distance ... distance from the closest train station

The closer to the station, the more valuable is the lot. The limitation is that this 
variable cannot account for the weight of the train station. For example, although a point located $100 \mathrm{~m}$ from Tokyo Station in Chuo ward is not equivalent to a point located $100 \mathrm{~m}$ from another small station in Chuo ward, they are treated as equivalent in this model. One possible remedy is weighting by (log of) the radius from Tokyo Station.

\section{$\underline{\text { Results and Implications }}$}

The results are almost the same as were first expected. Strong effects on land prices are caused by the variables FAR and location including distance from the station and ward dummy. Observing the location dummy variables, Minato ward has the largest coefficient of wards in many years. This fact is almost the same as the office rents; the average rent in Chiyoda is highest and Minato is the second. Other variables except fire prevention zone dummy show consistent signs of their coefficients. Thable42: Outputs of Hedonic Analysis] Note that fewer numbers of independent variables are statistically significant during the bubble economy, which Table 4-2 shows as shaded variables.

The goodness of fit, adjusted $R^{2}$, range very high, $0.85-0.90 . R^{2}$ is defined as the regression sum of squares over the total variation of estimates: $1-R^{2}$ is the ratio of the residual variation to the total variation. This is a portion which cannot be explained by the model. The adjusted $\mathrm{R}^{2}$ is calculated as follows, taking degree of freedom into account. Since the number of survey points are different by years in this analysis, the adjusted $R^{2}$ is applied. 
Table 4-2: Outputs of Hedonic Analysis

\begin{tabular}{|c|c|c|c|c|c|c|c|c|c|c|c|c|c|c|c|c|c|c|}
\hline & 1983 & 1984 & 1985 & 1986 & 1987 & 1988 & 1989 & 1990 & 1991 & 1992 & 1993 & 1994 & 1995 & 1996 & 1997 & 1998 & 1999 & 2000 \\
\hline $\mathrm{N}$ & 75 & 185 & 171 & 143 & 127 & 183 & 209 & 206 & 214 & 221 & 229 & 304 & 361 & 396 & 395 & 402 & 397 & 410 \\
\hline $\mathrm{R}$ & 0.936 & 0.924 & 0.934 & 0.941 & 0.956 & 0.941 & 0.929 & 0.934 & 0.934 & 0.937 & 0.942 & 0.946 & 0.945 & 0.942 & 0.935 & 0.931 & 0.926 & 0.922 \\
\hline $\mathrm{R}^{2}$ & 0.876 & 0.854 & 0.872 & 0.885 & 0.915 & 0.886 & 0.864 & 0.872 & 0.872 & 0.879 & 0.887 & 0.896 & 0.893 & 0.887 & 0.875 & 0.867 & 0.858 & 0.85 \\
\hline adjusted $\mathrm{R}$ & 0.845 & 0.841 & 0.859 & 0.871 & 0.903 & 0.876 & 0.853 & 0.862 & 0.862 & 0.87 & 0.879 & 0.89 & 0.888 & 0.882 & 0.87 & 0.862 & 0.852 & 0.844 \\
\hline 1- adj $R^{2}$ & 0.1551 & 0.1589 & 0.1405 & 0.1286 & 0.0969 & 0.1239 & 0.1470 & 0.1382 & 0.1378 & 0.1301 & 0.1210 & 0.1097 & 0.1118 & 0.1175 & 0.1302 & 0.1383 & 0.1476 & 0.1561 \\
\hline SEE & 0.3283 & 0.3496 & 0.3772 & 0.3969 & 0.3895 & 0.3732 & 0.402 & 0.3835 & 0.3911 & 0.3929 & 0.3756 & 0.3408 & 0.3122 & 0.2934 & 0.2951 & 0.3036 & 0.3122 & 0.3189 \\
\hline SSR & 45.066 & 120.19 & 150.107 & 153.903 & 180.375 & 181.357 & 197.4 & 190.167 & 206.062 & 229.395 & 235.778 & 287.481 & 280.121 & 256.614 & 230.617 & 231.647 & 224.392 & 226.268 \\
\hline SSE & 6.357 & 20.535 & 22.055 & 20.01 & 16.837 & 23.254 & 31.185 & 27.942 & 30.28 & 31.642 & 30.049 & 33.45 & 33.627 & 32.708 & 33.01 & 35.584 & 37.144 & 40.062 \\
\hline SST & 51.423 & 140.72 & 172.162 & 73.913 & 197.212 & 04.611 & 228.585 & 218.109 & 236.342 & 261.037 & 265.827 & 320.931 & 313.748 & 289.322 & 263.627 & 267.231 & 261.536 & 266.33 \\
\hline $\mathrm{F}$ & 27.882 & 65.55 & 70.329 & 65.118 & 79.278 & 86.827 & 81.447 & 86.208 & 89.828 & 9.079 & 1.422 & 5.011 & 1.594 & 8.755 & 6.519 & 167.519 & 153.443 & 148.354 \\
\hline \multicolumn{19}{|c|}{ Standardized Coefficients } \\
\hline Chiyoda & 0.111 & 0.131 & 0.172 & 0.159 & 0.238 & 251 & 0.238 & 0.206 & 0.198 & 0.177 & 0.188 & 0.176 & 0.164 & 0.126 & 0.092 & 0.114 & 0.125 & 0.139 \\
\hline Chuo & 0.165 & 0.134 & 0.172 & 0.186 & 0.22 & 0.233 & 0.201 & 0.188 & 0.176 & .156 & 0.174 & 0.159 & 0.133 & 0.096 & 0.072 & 0.08 & .091 & 0.091 \\
\hline Minato & 0.106 & 0.152 & 0.179 & 0.189 & 0.379 & 0.377 & 0.346 & 0.325 & 0.281 & 0.263 & 0.255 & 0.213 & 0.179 & 0.152 & 0.136 & 0.152 & 0.153 & 0.165 \\
\hline Shinjuku & 0.157 & 0.07 & 0.097 & 0.097 & 0.227 & 0.178 & 0.137 & 0.105 & 0.12 & 0.092 & 0.121 & 0.111 & 0.095 & 0.067 & 0.062 & 0.067 & 0.08 & 0.106 \\
\hline Bunkyo & 0.001 & 0.018 & 0.022 & 0.029 & 0.047 & 049 & 0.04 & 0.005 & 0.004 & 0.002 & 0.039 & 0.055 & 0.055 & 0.023 & 0.023 & 0.001 & 0.016 & 0.022 \\
\hline Taito & 0.037 & -0.051 & -0.033 & -0.047 & .056 & -0.076 & -0.088 & -0.073 & -0.095 & -0.1 & -0.06 & -0.034 & -0.02 & -0.054 & -0.081 & -0.092 & -0.084 & -0.073 \\
\hline Shibuya & 0.14 & 0.15 & 158 & 176 & 251 & 0.285 & 0.228 & 0.211 & 0.244 & 212 & .215 & 0.192 & 0.172 & 146 & 0.147 & .162 & 0.163 & 0.179 \\
\hline zone & 0.072 & 0.033 & 029 & 101 & .185 & 0 & 094 & 119 & 0.09 & 152 & .139 & 136 & 108 & 0.068 & .063 & 0.048 & 0.03 & 0.004 \\
\hline size & 0.147 & 0.055 & 019 & 0.115 & -0.008 & 023 & 0.034 & 0.055 & 0.046 & .054 & .038 & 0.059 & 0.064 & 0.077 & 0.095 & 0.104 & 0.118 & 0.131 \\
\hline stwidth & 0.103 & 0.146 & 0.129 & 15 & 057 & 0.048 & 0.073 & 0.039 & 0.09 & 0.076 & .085 & 0.086 & .105 & 0.121 & .125 & 136 & .142 & 0.139 \\
\hline $2 s t$ & 0.055 & 0.069 & 0.133 & 108 & 0.01 & 0.057 & 0.057 & 0.058 & .062 & 0.06 & .071 & 0.076 & 0.075 & 0.07 & .075 & 074 & .082 & 0.091 \\
\hline 3or4st & 0.08 & 0.053 & 0.077 & 059 & -0.001 & 0.026 & 0.045 & 0.035 & 029 & 0.029 & 0.039 & 0.051 & 0.038 & 0.043 & 0.057 & 65 & 0.071 & 0.071 \\
\hline distance & -0.113 & -0.09 & -0.093 & -0.076 & .061 & 0.053 & -0.036 & -0.036 & -0.044 & 036 & -0.03 & 057 & .068 & -0.072 & -0.088 & 083 & -0.087 & -0.091 \\
\hline fire & 0.017 & -0.032 & -0.061 & -0.069 & 0.256 & 139 & 0.113 & 152 & 168 & 04 & .107 & 128 & .079 & 0.069 & 0.018 & -0.051 & -0.077 & -0.091 \\
\hline FAR & 0.58 & 0.664 & 0.663 & 587 & 0.62 & 0.599 & 0.526 & 0.507 & 0.486 & 0.515 & 0.534 & 0.506 & 0.573 & 0.604 & 0.657 & 0.665 & 0.67 & 0.689 \\
\hline $\begin{array}{l}\text { t-stat } \\
\text { (constant) }\end{array}$ & 61.659 & 100.29 & .627 & .7 & 336 & 2.2 & & & & & 478 & 553 & 9.454 & .255 & 185 & 142 & 191 & 56.151 \\
\hline Chiyoda & 1.546 & 3.095 & 305 & 953 & 591 & 093 & 5.845 & 5.216 & 353 & 069 & .474 & 6.302 & 6.38 & 4.965 & 3.435 & .153 & .353 & 4.794 \\
\hline Chuo & 2.472 & 3.463 & 4.636 & 299 & 652 & 067 & 5.35 & 117 & 027 & 679 & 5.336 & 6.03 & 5.512 & 4.012 & 2.823 & 3.057 & 3.309 & 3.275 \\
\hline Minato & 1.653 & 3.659 & 4.561 & 912 & 163 & 9.52 & 8.724 & 424 & 865 & 629 & 7.596 & 7.943 & 7.219 & 6.226 & 5.231 & 5.709 & 5.54 & 5.859 \\
\hline Shinjuku & 2.149 & 1.639 & 2.371 & 2.229 & 599 & 4.469 & 3.34 & 689 & 3.233 & 2.625 & 3.505 & 3.99 & 3.691 & 2.67 & 2.329 & 2.472 & 2.816 & 3.672 \\
\hline Bunkyo & 0.022 & 0.486 & 0.58 & 745 & 411 & 1.379 & 1.089 & 0.153 & 109 & 0.069 & 1.272 & 2.183 & 2.351 & 1.02 & 0.965 & 0.054 & 0.623 & 0.862 \\
\hline Taito & 0.486 & -1.258 & -0.858 & -1.155 & -1.469 & -2.074 & -2.396 & -2.083 & -2.715 & -3.154 & -1.892 & -1.33 & -0.858 & -2.312 & -3.238 & -3.663 & -3.224 & -2.729 \\
\hline Shibuya & 1.991 & 3.619 & 3.968 & 4.313 & 6.576 & 7.571 & 5.918 & 5.773 & 6.878 & 6.316 & 6.56 & 7.354 & 7.077 & 6.089 & 5.787 & 6.277 & 6.086 & 6.563 \\
\hline zone & 0.362 & 0.439 & 0.41 & 1.222 & -2.215 & .001 & 1.325 & 1.796 & 396 & 2.402 & 2.373 & 3.283 & 2.81 & 1.749 & 1.521 & 1.151 & 0.721 & 0.102 \\
\hline size & 2.519 & 1.595 & 0.542 & 2.557 & -0.235 & 0.724 & 1.058 & 1.73 & 1.464 & 1.815 & 1.383 & 2.592 & 3.038 & 3.764 & 4.338 & 4.648 & 5.066 & 5.633 \\
\hline stwidth & & 2.988 & 2.687 & 2.95 & 1.153 & 1.148 & 1.686 & 0.912 & 2.091 & 1.842 & 2.281 & 2.735 & 3.684 & 4.365 & 4.235 & 4.525 & 4.545 & 4.585 \\
\hline 2st & 1.065 & 2.064 & 3.994 & 3.181 & 0.292 & 1.929 & 1.884 & 1.958 & & 2.13 & 2.699 & 3.531 & 3.798 & 3.616 & 3.677 & 3.624 & 3.828 & 4.235 \\
\hline 3or4st & 1.522 & 1.576 & 2.205 & 1.38 & -0.027 & 0.861 & 1.457 & 1.163 & 0.975 & 1.013 & 1.517 & 2.419 & 1.924 & 2.231 & 2.827 & 3.159 & 3.322 & 3.262 \\
\hline distance & -1.818 & -2.388 & -2.529 & -2.039 & -1.718 & -1.649 & -1.127 & -1.13 & -1.408 & -1.236 & -1.071 & -2.508 & -3.291 & -3.502 & -4.068 & -3.754 & -3.783 & -3.954 \\
\hline fire & 0.077 & -0.437 & -0.85 & -0.842 & 3.032 & 1.9 & 1.643 & 2.291 & 2.717 & 1.755 & 1.89 & 3.021 & 1.997 & 1.682 & -0.416 & -1.176 & -1.733 & -2.076 \\
\hline FAR & 4.709 & 9.057 & 9.09 & 7.683 & 8.994 & 9.851 & 8.483 & 8.038 & 7.758 & 8.626 & 9.587 & 11.198 & 14.142 & 15.132 & 15.116 & 15.185 & 14.773 & 15.447 \\
\hline
\end{tabular}

Note: Dark shaded variables are significant within $95 \%$ confidence interval and light ones are within $90 \%$. 
Let $u_{\mathrm{t}}$ be hedonic residual variable.

$\mathrm{u}_{\mathrm{t}}=1$ - adjusted $\mathrm{R}_{\mathrm{t}}^{2}=\left(1-\mathrm{R}_{\mathrm{t}}^{2}\right)\left(\mathrm{N}_{\mathrm{t}}-1\right) /\left(\mathrm{N}_{\mathrm{t}}-\mathrm{k}\right)$

$\mathrm{N}_{\mathrm{t}}$ : the number of observation

$\mathrm{k}$ : the number of independent variables (in all models $\mathrm{k}=16$ )

When $u_{t}$ gets large, that is, the unpredictable component gets large. One new theory can explain how this residual term may affect land prices: this uncertainty acts as noise in estimates of asset prices, which leads to a decrease the current value as well as standard option value (Childs et al. (2000)). Observing the result, Table 4-2, $\mathrm{u}$ became higher in $1983-85,1989-91$, and 1998-2000, when the growth rates of land prices were close to zero [see. Figure 2-1]. This fact may imply that other factors besides lot attributes have affected land prices during these years.

\section{Pool Data Analysis}

\section{Methodology}

The model in this research is similar to those by Quigg (1993), however, my research uses pool data focusing on variation of uncertainty over time.

\section{$<$ Data Pooling $>$}

The land price index data from 1985 to 2000 in Tokyo 8 Wards are used for the dependent variable. The total number of the data set is 4,368 and the number of the data is larger in the recent years Thble2 - The Number of Surves Points]. Every data is converted to real terms by the GDE deflator. Here is a description of variables in the model Table 4-1: Model Description].

As mentioned in the previous section, some points have been surveyed every year 
in this period and others are added or deleted in some years. First, surveyed points are chosen which have been surveyed continually for 16 years, from 1985 through 2000 . The missing data then have been compensated for referring to the data of its previous year and the next year ${ }^{9}$. Since land prices in the previous year are also listed in the index, the previous year's data can be made up by inserting these prices and the amenity data of years before and after. A total 480 data set consists of the 31 survey points which are continually surveyed for at least 16 years.

\section{$<$ Ordinal Least Square Method $>$}

My data contains 16 years' variations in time-series economic variables; therefore, it is difficult to capture aggregate effects of economic variables on land prices. In other words, though each economic variable has a certain effect on land prices, the portion the variables can explain for land prices is rather fixed ${ }^{10}$. Therefore, the Fixed-effects Model is not applicable. Rather, it is reasonable to assume the combined error component is arbitrarily large: therefore the ordinary least squares is applied here ${ }^{11}$.

As a first step, all possible data that are thought to affect the land prices were input. Then significant effects in wards and over time were examined. Economic variables and several amenity variables from data attached to the Land Price Index were selected for independent variables then multiple regression models were

\footnotetext{
${ }^{9}$ Some points were not surveyed in the 1987 data so 12 points in the 1987 data are included in the model. As the compensated data of 8 points in the 1985 do not show the previous year's data, they are excluded in the model which uses first difference.

${ }^{10}$ When dummy variables for each year are included in the models, they replace for the economic variables.

${ }^{11}$ Because of the limitations of the time-series data, the generalized least squares method is
} 
conducted.

$\ln L_{i t}=f\left(\right.$ economic variables $t$, lot characteristic variables and location variables $\left.{ }_{i}\right)$

$\ln \mathbf{L}_{\mathrm{it}}=\beta^{\prime}\left(\mathbf{X}_{\mathrm{t}}+\mathbf{X}_{\mathrm{i}}\right)$

$\mathbf{X}_{\mathrm{t}}$ : time-series component

aggregate data (no cross-sectional, time-series variables): $\mathrm{P}, \mathrm{K}^{12}, \mathrm{i}, \mathrm{y}^{13}, \sigma_{\mathrm{PM}}, \sigma, \mathrm{u}$

$\mathbf{X}_{\mathrm{i}}$ : cross-sectional component

dis-aggregate data (cross-sectional, no time-series variables): amenity variables

\section{The Data}

The data in the model are based on the models by Holland et al. (1998) and by Yoshida (1999). My objectives are identifying the way of uncertainty affects land prices. Learning about the sign of the investment-uncertainty relationship, (log-)linear regressions of land prices on various measures of uncertainty suffice for the objectives.

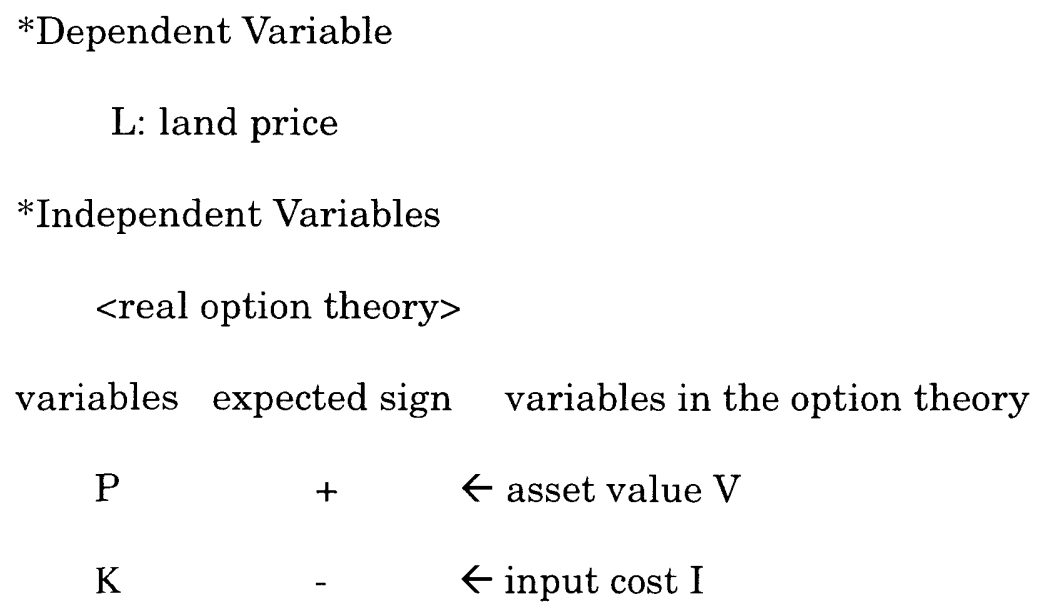

not applicable in this research.

${ }^{12} \mathrm{~K}$ is different by the four building types of the lot. Therefore, $\mathrm{K}$ involves slight crosssectional effects.

${ }^{13} \mathrm{y}$ is different by small business districts, which are subsets of wards. Therefore, $\mathrm{y}$ also 


$\begin{array}{lll}\mathrm{i} & - & \leftarrow \text { risk-free interest rate, } \mathrm{r}_{\mathrm{f}}, \\ \mathrm{y} & + & \leftarrow \text { dividend rate, } \delta \\ \sigma & + & \leftarrow \text { uncertainty over the asset value, } \sigma \\ \sigma_{\mathrm{PM}} & \leftarrow \text { covariance with the asset with market portfolio, } \sigma \mathrm{PM}\end{array}$

(0) L ... land price

Land Price Index in real terms (source: the National Land Agency)

Since this data are given as of January 1 every year, they are deflated by the previous years' deflators and regressed by independent variables of the previous years, otherwise noted. In the models, natural $\log$ of $\mathrm{L}$ is used as the dependent variables.

(1) P ... built asset price

Log of TPREAL ${ }^{14}$. (source: the Tokyo Stock Exchange Stock Price Index for the real estate industry) in real terms

As no data on built asset prices are publicly available, stock price index for the real estate industry is utilized in proxy to the asset prices. Quan and Titman (1999) show that the contemporaneous relation between yearly real estate price changes and stock return is quite high (0.62 in Japanese yen basis) in Japan. Yoshida (1999) examined

involves cross-sectional effects.

14 TPREAL is a capitalization weighted index and includes shares of all real estate companies listed in the First Section of the Tokyo Stock Exchange. The weight of each company varies daily. Companies have been added and deleted when they have been newly traded or 


\section{Empincal Testing of Real Option-Pricing Models Using Land Price Indexin Japan}

the correlation between real estate price changes and the price of market portfolio and showed that the stock price of the real estate industry has higher correlation with real estate price than with market portfolio.

As reviewed in the previous chapter, the value of the investment option is a convex function of the initial price, in other words, land price is a convex function of the asset price. Therefore, stock price should have positive relationship to land prices.

(2) $\mathrm{K}$... construction cost

Log of the Construction Cost Deflator in real terms (source: the Ministry of Construction)

This is monthly data and the value is the average so that has to be considered the lag. This deflator is given by building structure types, SRC (steel framed reinforced concrete), RC (reinforced concrete), S (steel framed), and W (wooden). The current structure types are provided by the Index and identified in each lot: this variable is time-series and lot specific. Note that some structure data lacks data when no structure was on the lot. In this case, the data of the years before and after is substituted. B (block) which appeared in the 1985 data set is proxy for W. In order to distinguish these four types of construction cost, the ratios of construction cost, which is calculated from the Basic Unit of Construction Cost by the Ministry of Construction, are multiplied by each deflator.

It can be easily imagined that the smaller cost of investment leads to the larger value of the investment opportunity. Therefore, the construction cost should have negative relationship to land prices because the real estate price is the sum of 
investment cost and an opportunity cost of investing, land price.

(3) i ... risk-free interest rate

$\mathrm{i}=(1+\mathrm{Tbill}) /(1+$ inflation rate $)-1$

Tbill: the Japanese goverment bond yield in real terms (source: IMF)

Inflation rate: GED deflator (source: the Economic Planning Agency)

As seen in the above chapter, option value is a present value of the difference between the future asset value and investment cost. Therefore, the interest rate affects option prices in two opposite direction: a lower interest rate increases the present value of the cost of investment as well as the option value. Dixit and Pindyck (1998) note "the net effect is weak and sometimes even ambiguous."

(4) y ... rent yield rate ra $^{15}$

real MTB-IKOMA Real Estate Investment Index (source: the Mitsubishi Trust and Banking Corporation, and Ikoma Data Service System Co., Ltd.)

This Index is calculated on the basis of actual office rents classified in small business districts, which are subsets of wards. Since the Index records only business areas, rent yield rates of survey points that are located outside of the areas dealt with by the Index are approximated according to the statistics of the closest district. The Tokyo Central 8 Wards contain 42 areas of Index, whose 40 dividend rates are used in the model. With 40 variations of the economic variable, rent yield rates can help specify

${ }^{15}$ Instead of the yield rate variable y, this study also examines the expected growth rate in rent variable $\mathrm{g}$. The GDP growth rate can be substituted of the growth in rent (Quan and Titman (1999)) and included in the following models. The results are almost same as the models including $\mathrm{y}$. 
cross-sectional differences.

According to the real option theory, the yield rate is an opportunity cost of delaying construction of the project and instead keeping the option to invest alive; therefore, higher yield rate lowers land prices.

(5) $\sigma_{P M} \ldots$ systematic risk associated with owing developed real estate assets covariance of daily changes of TPREAL and of TOPIX ${ }^{16}$ prices

TOPIX: comprehensive stock price index

TPREAL: stock price index for real estate industries

In this model, TOPIX is assumed to be a market portfolio. First, daily changes of TPREAL prices and TOPIX prices as posted, without deflation, calculated. Then, covariance is calculated from about 270 daily returns through every calendar year. According to CAPM, lower systematic risk results in higher discount rate. Like situations mentioned about risk-free rate, the option value increases in demand side and lower construction cost in supply side. Again, if the effects which can be explained by the option theory is larger, the sign of the coefficient of $\sigma_{\mathrm{PM}}$ is negative.

(6) $\sigma \ldots$ total uncertainty with respect to built asset return

standard deviation of daily changes of TPREAL prices

Total uncertainty is approximated by standard deviation of daily changes of stock prices of real estate industries. Since TPREAL prices are utilized as asset prices, the standard deviation is volatility of the asset caused by any events, which are not

16 TOPIX is a weighted index by market value and includes all shares listed in the First Section of TSE. 
necessary to determine. The standard deviation is calculated from about 270 daily returns of TPREAL prices as posted through every calendar year.

An increase in uncertainty over asset prices raises the value of the option to invest, because larger uncertainty increases the upside potential payoff from the option, leaving downside payoff unchanged at zero by not exercising the option. Therefore, total uncertainty should have positive relationship to land prices.

(7) u ... cross-sectional uncertainty

residual component of cross-sectional hedonic models

$\mathrm{u}_{\mathrm{t}}=1-$ adjusted $\mathrm{R}_{\mathrm{t}}^{2}=\left(1-\mathrm{R}_{\mathrm{t}}^{2}\right)\left(\mathrm{N}_{\mathrm{t}}-1\right) /\left(\mathrm{N}_{\mathrm{t}}-\mathrm{k}\right)$

As mentioned in the previous section, $u_{t}$ is one noise in estimates of asset prices, which leads to a decrease the current value as well as standard option value (Childs et al. (2000)). Since larger noise will lower the land prices, the predicted sign of the coefficient is negative.

(8) amenity variables

The same attribute data as in hedonic models in the previous research are again included in the pool model. (see. the descriptions of the variables in the previous section) 


\section{Results and Discussion}

The results of amenity variables are almost the same as the results of the previous hedonic analysis. On the other hand, the results of time-series economic variables need to be further examined [Thbes-1: Regression Resuls (evel].

$<$ time-series economic variables $>$

One possible reason why some variables are not stable among the lags is that these variables are highly correlated with each other. The variables $\sigma_{\mathrm{t}}$ and $\sigma_{\mathrm{PM}} \mathrm{t}$ are highly positively correlated, which causes a large variance in the estimates ${ }^{17}$.

(1) P ... positive sign, which can be explained by both the neoclassic theory and the real option theory

(2) K ... positive sign, which is opposite from both the neoclassic theory and the real option theory

(3) i ... negative sign, which is can be explained by both the neoclassic theory and the real option theory

(4) y ... negative sign, which can be explained by both the neoclassic theory and the real option theory

(5) $\sigma_{P M} \ldots$ negative sign, which can be explained by both the neoclassic theory and

${ }_{17}$ The high correlation between the variables $\sigma_{\mathrm{PM}} \mathrm{t}$ and $\sigma_{\mathrm{t}}$ doesn't mean that the covariance of real estate stock markets and stock markets, and the standard deviation of real estate stock 
the real option theory

(6) $\sigma \ldots$ positive sign, which can be only explained by the real option theory

(7) $\mathrm{u}$... negative sign, which can be explained by noise based on the real option theory.

(8) Amenity variables

Results are almost the same as the previous hedonic analysis. All coefficients of amenity variables except the dummy variable of fire prevention zone are significant within $95 \%$ confidence interval.

\section{Time-series Analysis}

In order to identify stationarity and integration in the above time-series variables, autocorrelation (ACF) plots and partial autocorrelation (PACF) plots are observed, though the number of data is only $17^{18}$. These plots show that $\sigma$ and $\sigma \mathrm{PM}$ seem stationary and that other variables also seem stationary when they are taken one difference from one observation to the next, $I(1)^{19}$. I(1) process has a perfect memory of the previous value - but only the previous value. Note that an autoregressive model AR(1) can be approximated by an I(1) model when the regression coefficient is near 1.0.

markets are highly correlated in Japan because the number of time-series data is only 17 .

18 The ACF and PACF plots of the average land prices in Tokyo from 1970 through 2000 show land prices seem AR(2). GDP from 1975 through 1999 seems AR(1). Monthly government bond yield from 1966 through 1999 seems AR(1).

19 The one differences of every variable of $\mathrm{K}$ seem to have a first-order autoregressive, $\operatorname{ARIMA}(1,1,0)$. 
(Pindyck and Rubinfeld (1998))

\section{(1) first difference}

Let's take first differences of the land price variable and the economic variables and employ OLS.

$\ln \mathbf{L}_{\mathrm{it}}=\ln \mathbf{L}_{\mathrm{it}-1}+\beta^{\prime}\left(\Delta \mathbf{X}_{\mathrm{t}}+\mathbf{X}_{\mathrm{i}}\right)$

$\Delta \mathbf{X}_{\mathrm{t}}=\mathbf{X}_{\mathrm{t}}-\mathbf{X}_{\mathrm{t}-1}$

\section{Results Thable-2: Regressin Results one diference]}

(0) $\ln \mathrm{L}_{\mathrm{t}-1}$

Since the coefficient is very close to one, other independent variables explain the changes of land price.

$\ln \left(\mathrm{L}_{\mathrm{t}} / \mathrm{L}_{\mathrm{t}-1}\right) \sim \beta^{\prime}\left(\Delta \mathbf{X}_{\mathrm{t}}+\mathbf{X}_{\mathrm{i}}\right)$

(1) $\Delta \mathrm{P}$... positive sign, which can be explained both the neoclassic theory and the real option theory

(2) $\Delta \mathrm{K}$... positive sign, which is opposite from both the neoclassic theory and the real option theory

(3) $\Delta \mathrm{i}$... negative sign, which is can be explained by both the neoclassic theory and the real option theory

(4) $\Delta y$... negative sign, which is can be explained by both the neoclassic theory and 
the real option theory

(5) $\Delta \sigma_{\mathrm{PM}} \ldots$ negative sign, which is can be explained by both the neoclassic theory and the real option theory

(6) $\Delta \sigma \ldots$ positive sign, which can be only explained by the real option theory

(7) $\Delta \mathrm{u}$... negative sign, which can be explained by noise based on the real option theory.

\section{(8) Amenity variables}

Most ward dummy variables are not statistically significant. On the other hand, the distance variable and other lot characteristic variables except the zone dummy variable are significant within $95 \%$ confidence interval, and these coefficients have the same sign as the previous models. This means that the land price growth is independent in these words; however, it is also affected by lot characteristics and distance from the closest train station.

\section{(2) Distributed Lag}

It is apparent that the correlation between land prices at time $t$ and those at the precious year time t- 1 is very high; therefore, it is highly possible that any serial correlation in variables. In addition, a substantial period of time may pass between the economic decision-making period and the impact of a change in the land price variable; that is, economic environment of the previous years have also affected the current land 
prices. In order to consider that economic changes can be distributed over years, the distributed lag model is employed. In this paper, the geometric lag estimation method with a single lagged dependent variable is utilized. This model accounts for the timeadjustment process and the transformation procedure can reduce any serial correlation that was originally present.

Original: $\ln \mathbf{L}_{\mathrm{it}}=\alpha+\beta^{\prime}\left(\mathbf{X}_{\mathrm{t}}+\mathbf{X}_{\mathrm{i}}\right)+\varepsilon_{\mathrm{t}}$

Geometric Lag: $\ln \mathbf{L}_{\mathrm{it}}=\alpha+\beta^{\prime}\left(\left(\mathbf{X}_{\mathrm{t}}+\mathbf{X}_{\mathrm{i}}\right)+\mathrm{w}\left(\mathbf{X}_{\mathrm{t}-1}+\mathbf{X}_{\mathrm{i}}\right)\right)+\varepsilon_{\mathrm{t}}$

Transformed: $\ln \mathbf{L}_{\mathrm{it}}=\alpha(1-\mathrm{w})+\mathrm{w} \ln \mathbf{L}_{\mathrm{it}-1}+\beta^{\prime}\left(\mathbf{X}_{\mathrm{t}}+\mathbf{X}_{\mathrm{i}}\right)+\mathrm{u}_{\mathrm{t}}$ where $u_{t}=\varepsilon_{t}-\mathrm{w} \varepsilon_{t-1}$

It is assumed that the error term is normally distributed, independent of $\mathbf{X}$, and neither serially correlated nor heteroscedastic. Note that the variables, $\mathbf{X}_{\mathrm{i}}$, are constant over years.

\section{Results Table5-3: Regression Resuls (distributed lag)]}

The weight of dependent variable is estimated as $\mathrm{w}=0.919$.

(1) P ... positive sign, which can be explained by both the neoclassic theory and the real option theory

(2) K ... negative sign, which can be explained by both the neoclassic theory and the real option theory

(3) i ... positive sign, which is opposite from both the neoclassic theory and the real option theory 


\section{Emprical Testing of Real Option-Pricing Models Using Land Price Index in Japen}

This result may be because the interest rate affects option prices in two opposite direction: a lower interest rate increases the present value of the cost of investment as well as the option value.

(4) y ... negative sign, which can be explained by both the neoclassic theory and the real option theory

(5) $\sigma_{P M} \ldots$ negative sign, which can be explained by both the neoclassic theory and the real option theory

(6) $\sigma \ldots$ positive sign, which can be only explained by the real option theory The standardized coefficient of $\sigma$ is the second largest after the variable of the previous year's land price. This implies that total uncertainty affect largely affect on land prices.

(7) $\mathrm{u}$... negative sign, which can be explained by noise based on the real option theory.

\section{(8) Amenity variables}

Results are almost the same as the previous models; however, more amenity variables are not significant. This may be because the amenity variables do not change over times, while the distributed lag method is useful for identifying variables that are changing over times. 
Table 5-1: Regression Results (level)

Coefficients

\begin{tabular}{|c|c|c|c|c|c|}
\hline Model & $\begin{array}{l}\text { Unstandardi } \\
\text { zed } \\
\text { Coefficients } \\
\text { B }\end{array}$ & Std. Error & \begin{tabular}{|} 
Standardize \\
$d$ \\
Coefficients \\
Beta
\end{tabular} & $t$ & Sig. \\
\hline (Constant) & 8.37 & 0.315 & & 26.581 & 0 \\
\hline $\mathrm{P}$ & 0.65 & 0.020 & 0.229 & 32.052 & 0 \\
\hline $\mathrm{K}$ & 0.6 & 0.056 & 0.070 & 10.658 & 0 \\
\hline i & -0.01875 & 0.008 & -0.018 & -2.317 & 0.021 \\
\hline$y$ & -0.282 & 0.005 & -0.411 & -53.044 & \\
\hline$\sigma_{P M}$ & -0.177 & 0.014 & -0.151 & -12.958 & 0 \\
\hline$\sigma$ & 0.245 & 0.028 & 0.112 & 8.696 & \\
\hline u & -15.146 & 0.512 & -0.198 & -29.602 & \\
\hline Chiyoda & 0.486 & 0.026 & 0.137 & 18.489 & 0 \\
\hline Chuo & 0.37 & 0.027 & 0.097 & 13.904 & \\
\hline Minato & 0.496 & 0.024 & 0.152 & 20.782 & \\
\hline Shinjuku & 0.196 & 0.022 & 0.065 & 8.743 & \\
\hline Bunkyo & $9.04 \mathrm{E}-02$ & 0.025 & 0.025 & 3.670 & \\
\hline Taito & -0.119 & 0.025 & -0.033 & -4.760 & 0 \\
\hline Shibuya & 0.511 & 0.024 & 0.153 & 21.704 & 0 \\
\hline ZONE & $1.80 \mathrm{E}-01$ & 0.027 & 0.077 & 6.557 & 0 \\
\hline SIZE & 2.01E-04 & 0.000 & 0.085 & 14.073 & \\
\hline ST.WIDTH & $7.18 \mathrm{E}-03$ & 0.001 & 0.076 & 9.243 & 0 \\
\hline 2STREETS & 0.138 & 0.016 & 0.049 & 8.714 & 0 \\
\hline 3-4STREETS & 0.206 & 0.030 & 0.039 & 6.853 & 0 \\
\hline DISTANCE & $-2.30 E-04$ & 0.000 & -0.060 & -9.944 & 0 \\
\hline FIRE & $-2.72 \mathrm{E}-02$ & 0.029 & -0.012 & -0.953 & 0.341 \\
\hline FAR & $2.61 \mathrm{E}-03$ & 0.000 & 0.485 & 40.781 & 0 \\
\hline
\end{tabular}

Dependent Variable: InLt

\begin{tabular}{|c|c|c|c|}
\hline $\mathrm{N}$ & 4367 & & \\
\hline$R$ & $R^{2}$ & adjusted $R^{2}$ & SEE \\
\hline 0.943 & 0.889 & 0.888 & 0.3811 \\
\hline $\mathrm{F}$ & 1579.232 & & \\
\hline
\end{tabular}


Table 5-2: Regression Results (difference)

Coefficients

\begin{tabular}{|c|c|c|c|c|c|}
\hline Model & $\begin{array}{l}\text { Unstandardi } \\
\text { zed } \\
\text { Coefficients } \\
\text { B }\end{array}$ & Std. Error & $\begin{array}{l}\text { Standardize } \\
d \\
\text { Coefficients } \\
\text { Beta }\end{array}$ & $t$ & Sig. \\
\hline (Constant) & 0.6 & 0.043 & & 14.067 & 0 \\
\hline $\ln L_{t-1}$ & 0.949 & 0.003 & 0.951 & 295.118 & 0 \\
\hline$\Delta \mathrm{P}$ & 0.482 & 0.008 & 0.135 & 63.137 & 0 \\
\hline$\Delta \mathrm{K}$ & 4.156 & 0.091 & 0.097 & 45.842 & 0 \\
\hline$\Delta \mathrm{i}$ & -0.02395 & 0.002 & -0.024 & -14.457 & 0 \\
\hline$\Delta y$ & -0.05986 & 0.002 & -0.056 & -26.781 & 0 \\
\hline$\Delta \sigma_{\mathrm{PM}}$ & -0.243 & 0.005 & -0.301 & -50.461 & 0 \\
\hline$\Delta \sigma$ & 0.507 & 0.011 & 0.254 & 46.806 & 0 \\
\hline$\Delta \mathrm{u}$ & -8.404 & 0.186 & -0.097 & -45.290 & 0 \\
\hline Chiyoda & 0.0004514 & 0.008 & 0.000 & 0.058 & 0.953 \\
\hline Chuo & -0.006923 & 0.008 & -0.002 & -0.890 & 0.374 \\
\hline Minato & -0.006495 & 0.007 & -0.002 & -0.920 & 0.358 \\
\hline Shinjuku & 0.01009 & 0.006 & 0.003 & 1.557 & 0.12 \\
\hline Bunkyo & -0.003865 & 0.007 & -0.001 & -0.543 & 0.587 \\
\hline Taito & $-2.27 \mathrm{E}-02$ & 0.007 & -0.006 & -3.150 & 0.002 \\
\hline Shibuya & 0.01408 & 0.007 & 0.004 & 2.014 & 0.044 \\
\hline ZONE & -0.01174 & 0.008 & -0.005 & -1.474 & 0.14 \\
\hline SIZE & 1.61E-05 & 0.000 & 0.007 & 3.884 & 0 \\
\hline ST.WIDTH & $6.22 \mathrm{E}-04$ & 0.000 & 0.007 & 2.756 & 0.006 \\
\hline 2STREETS & $8.15 \mathrm{E}-03$ & 0.005 & 0.003 & 1.774 & 0.076 \\
\hline 3-4STREETS & 0.02805 & 0.009 & 0.005 & 3.216 & 0.001 \\
\hline DISTANCE & $-1.569 \mathrm{E}-05$ & 0.000 & -0.004 & -2.342 & 0.019 \\
\hline FIRE & $-3.30 \mathrm{E}-02$ & 0.008 & -0.014 & -4.044 & 0 \\
\hline FAR & $2.12 \mathrm{E}-04$ & 0.000 & 0.039 & 10.415 & 0 \\
\hline
\end{tabular}

Dependent Variable: InLt

\begin{tabular}{|c|c|c|c|}
\hline $\mathrm{N}$ & 4340 & & \\
\hline $\mathrm{R}$ & $R^{2}$ & adjusted $R^{2}$ & SEE \\
\hline 0.995 & 0.991 & 0.991 & $\begin{array}{l}0.1097 \\
\end{array}$ \\
\hline$F$ & 20165.806 & & \\
\hline
\end{tabular}


Table 5-3: Regression Results (distributed lag)

Coefficients

\begin{tabular}{|c|c|c|c|c|c|}
\hline Model & $\begin{array}{l}\text { Unstandardi } \\
\text { zed } \\
\text { Coefficients } \\
\text { B }\end{array}$ & IStd. Error & $\begin{array}{l}\text { Standardize } \\
\quad d \\
\text { Coefficients } \\
\text { Beta }\end{array}$ & $t$ & Sig. \\
\hline (Constant) & 0.882 & 0.121 & & 7.305 & 0 \\
\hline $\operatorname{lnL} L_{t-1}$ & 0.919 & 0.005 & 0.921 & 172.139 & 0 \\
\hline $\mathrm{P}$ & 0.139 & 0.008 & 0.049 & 17.737 & 0 \\
\hline K & -0.297 & 0.021 & -0.035 & -14.282 & 0 \\
\hline i & 0.05337 & 0.003 & 0.052 & 18.266 & 0 \\
\hline y & -0.03659 & 0.002 & -0.053 & -15.424 & 0 \\
\hline$\sigma_{P M}$ & -0.157 & 0.005 & -0.134 & -31.950 & 0 \\
\hline$\sigma$ & 0.374 & 0.010 & 0.171 & 36.978 & 0 \\
\hline $\mathrm{u}$ & -0.759 & 0.202 & -0.010 & -3.755 & 0 \\
\hline Chiyoda & 0.0241 & 0.010 & 0.007 & 2.467 & 0.014 \\
\hline Chuo & 0.009019 & 0.010 & 0.002 & 0.926 & 0.354 \\
\hline Minato & 0.02364 & 0.009 & 0.007 & 2.637 & 0.008 \\
\hline Shinjuku & 0.01808 & 0.008 & 0.006 & 2.241 & 0.025 \\
\hline Bunkyo & $5.76 \mathrm{E}-03$ & 0.009 & 0.002 & 0.652 & 0.514 \\
\hline Taito & -0.01596 & 0.009 & -0.004 & -1.784 & 0.074 \\
\hline Shibuya & 0.0373 & 0.009 & 0.011 & 4.209 & 0 \\
\hline ZONE & $-9.60 \mathrm{E}-03$ & 0.010 & -0.004 & -0.968 & 0.333 \\
\hline SIZE & $2.34 \mathrm{E}-05$ & 0.000 & 0.010 & 4.482 & 0 \\
\hline ST.WIDTH & $9.41 \mathrm{E}-04$ & 0.000 & 0.010 & 3.356 & 0.001 \\
\hline 2STREETS & 0.01698 & 0.006 & 0.006 & 2.967 & 0.003 \\
\hline 3-4STREETS & 0.04261 & 0.011 & 0.008 & 3.940 & 0 \\
\hline DISTANCE & $-1.38 \mathrm{E}-05$ & 0.000 & -0.004 & -1.647 & 0.1 \\
\hline FIRE & $-1.66 \mathrm{E}-02$ & 0.010 & -0.007 & -1.621 & 0.105 \\
\hline FAR & $3.43 \mathrm{E}-04$ & 0.000 & 0.064 & 12.983 & \\
\hline
\end{tabular}

Dependent Variable: InLt

\begin{tabular}{|c|c|c|c|}
\hline $\mathrm{N}$ & 4340 & & \\
\hline$R$ & $\mathrm{R}^{2}$ & adjusted $R^{2}$ & SEE \\
\hline 0.993 & 0.986 & 0.986 & 0.1359 \\
\hline $\mathrm{F}$ & 13070.918 & & \\
\hline
\end{tabular}




\section{Summary and Discussion}

The results favor the application of the real option theory in land prices. Examining the standard coefficients of the economic variables, the option-based pricing models identify the role of uncertainty in land price variations.

The coefficient of the total uncertainty in built asset return, $\sigma$, shows a positive sign in all models ${ }^{20}$, that is, the uncertainty increases the price of land, which is only explained by the option theory. In addition, the standardized coefficients of the total uncertainty $\sigma$ are substantially large in all models. This result supports the real option theory that the uncertainty has a substantial effect on increasing land prices.

The coefficient of the systematic risk $\sigma_{P M}$ shows a negative sign in all models ${ }^{20}$, which can be explained by both the option theory and the neoclassic-theory, the capital asset pricing model, CAPM. Note that the magnitudes of these two variables $\sigma$ and $\sigma_{\mathrm{PM}}$ are different, $\sigma$ is of standard deviation and $\sigma_{\mathrm{PM}}$ is multiples of standard deviations.

The coefficient of asset price $P$ has positive sign in all models ${ }^{20}$, which is explained by both the option theory and the neo-classical theory. Since the asset price variable $\mathrm{P}$ is approximated by the stock price index in these models, the standardized coefficient of $\mathrm{P}$ is not very large.

The coefficient of construction cost $K$ shows positive sign in both models: negative in one model that uses lagged terms, and positive in two models, one that uses the level of variables and another uses one difference of variables. This result is consistent with the fact that it usually takes more than two years to construct built assets from decision making. Effects of construction cost on land prices can be captured better in models that uses lagged terms than other models. 


\section{Emprical Testing of Real Option-Pricing Models Using Land Price Indexin Japan}

The coefficient of the risk-free interest rate $i$ shows both signs: negative in two models, one that uses the level of variables and another uses one difference of variables, and positive in the model that uses lagged terms. This result may be because the interest rate affects option prices in two opposite direction: a lower interest rate increases the present value of the cost of investment as well as the option value.

The coefficient of the rent yield rate $y$ has a negative sign in all models, which is also explained by both theories.

The coefficient of the residual of cross-sectional variable $u$ has negative signs in all models, which may imply that this uncertainty acts as noise in estimates of asset prices. This uncertainty decreases in the current value as well as standard option value (Childs et al. (2000)).

This paper examines the way uncertainty plays a role in land prices by combining both time-series and cross-sectional data. The results favor the real option theory rather than the neo-classical theory and identify the role of uncertainty in land prices variation over time. However, because of the data limitation of land prices in timeseries, the disturbance terms can not be specified, which consist of time-series-related disturbances, cross-section disturbances, or a combination of both. In addition, there are not sufficient numbers of survey points reported in the Index every year, so that panel data analysis is not conducted. With enough time-series data, ideally same lots, these uncertainties could be specified and the role of the uncertainties on land price variations could be determined.

Owing to real estate price data inavailability, this research uses aggregate data of

${ }^{20}$ Including models using the growth rate instead of the yield rate 
the stock price index. If actual micro real estate price data are available with for sufficient numbers of times, at least quarterly, the value of option could be estimated by combining real estate price data and land price data. Important consideration is how to obtain sufficient numbers of time series data of real estate that are dis-aggregate. 


\section{References}

Amram, M. \& Kulatilaka, N. (1999). Real Options, Boston: Harvard Business School Press

Ando, A., Uchida, R. and Yoshida. K. (1992.7), Space-time Analysis on Land Price Variations in Two Japanese Metropolitan areas Based on Land Price Functions, Journal of Japan Society of Civil Engineers, 449, 77-86

Bodie, Z., Kane, A. \& Marcus, A. J. (1999) Investments (4th ed.). New York: Irwin McGraw-Hill

Brealey, R. A. \& Myers S. C. (1996). Principles of Corporate Finance (5 ${ }^{\text {th }}$ ed.). New York: McGraw-Hill Companies, Inc.

Bruegmann, W. B. \& Fisher J. D. (1997). Real Estate Finance and Investments (10 ${ }^{\text {th }}$ ed.). New York: Irwin

Buetow, W. B. Jr. and Albert, J. D. (1998). The Pricing of Embeded Options in Real Estate Lease Contracts, Journal of Real Estate Research, 15, 3, 253-265

Capozza, D. R. and Helsley, R. W. (1990) The Stochastic City, Journal of Urban Economics, 28, 187-203

Capozza, D. R. and Sick, G. (1991). Valuing Long Term Leases: The Option to Redevelop. Journal of Real Estate Finance and Economics, 4, 209-223

Childs, P. D., Ott, S. H., and Riddiough, T. (2000), Valuation and Information Acquisition Policy for Claims Written on Noisy Real Assets, MIT Center for Real Estate Working Paper

Childs, P. D., Riddiough, T. and Triantis, A. J. (1995), Mixed-Uses and the Redevelopment Option, MIT Center for Real Estate Working Paper, WP56

Chriss, N. A. (1997). Black-Scholes and Beyond: Option Pricing Models. New York: McGraw-Hill

Clapp, J. M. and Giaccotto, C. (1998), Price Indices Based on the Hedonic Repeat-Sales Method: Application to the Housing Market, Journal of Real Estate Finance and Economics, 16, 1, 5-26

Colwell P. F. and Munneke H.J. (1999) Land Prices and Land Assembly in the CBD, Journal of Real Estate Finance and Economics, 18, 2, 163-180

DiPasquale, D. and Wheaton, W. (1996), Urban Economics and Real Estate Markets, Englewood cliffs: Prentice Hall

Dixit, A. K., \& Pindyck R. S. (1994). Investment under Uncertainty. Princeton: Princeton University Press

Doi, K. et al. (1994), An Impact Study of Land Policies Using the Asset Value Imputation Model, Journal of Japan Society of Civil Engineers, 494, 33-42

Fujita, M (1991) A Rational Expectations Equilibrium Model of Urban Growth and Land Markets. Journal of Real Estate Finance and Economics, 4, 225-265.

Geltner, D., Riddiough, T. \& Stojanovic, S (1996). Insights on the Effect of Land Use Choice: The Perpetual Option on the Best of Two Underlying Assets. Journal of Urban Economics, 39, 20-50

Grenadier, S. R. (1995). Valuing Lease Contracts A Real-Options Approach, Journal of Financial Economics, 38, 297-331

Grenadier, S. R. (1995). Local and National Determinants of Office Vacancies., Journal 
of Urban Economics, 37, 57-71

Grenadier, S. R. (1996). The Strategic Exercise of Options: Development Cascades and Overbuilding in Real Estate Markets. Journal of Finance, 51,5, 1653-1679

Grinblatt, M \& Titman, S. (1998). Financial Markets and Corporate Strategy. New York: Irwin McGraw-Hill

Hamilton, J. D. (1994), Time Series Analysis. Princeton: Princeton University Press

Hatta, T. and Ohkawara, T (1993). Population, Employment, and Land Price Distributions in the Tokyo Metropolitan Area, Journal of Real Estate Finance and Economics, 6, 103-128

Hendershott, P. H. and Ward, C. W. R (2000). Incorporating Option-like Features in the Valuation of Shopping Centers, Real Estate Finance, 10, 31-35

Hidano. N. et al. (1992.7), the Measuring the Benefits of Interregional Transportation Improvement Projects: A Hedonic Approach, Journal of Japan Society of Civil Engineers, 449, 67-76

Hidano. N. (1997), The Economic Measurement of Environmental and Infrastructure Projects: A Hedonic Approach, Tokyo: Keiso Shobo

Holland, S., Ott, S. \& Riddiough, T. (1998). The Role of Uncertainty in Investment: An Examination of Competing Investment Models Using Commercial Real Estate Data. Center for Real Estate Working Paper, 73. 1-38.

Hull, J. C. (1999) Options, Futures, and Other Derivatives (4th ed). Upper Saddle River, NJ: Prentice Hall

Ingersoll, J. E, Jr. and Ross, S. A. (1992), Waiting to Invest: Investment and Uncertainty, Journal of Business, 65, 1, 1-29

Kanemoto, Y. (1992.7), Theoretical Foundations of the Hedonic Approach to Benefit Estimation, Journal of Japan Society of Civil Engineers, 449, 47-56

Kwong, S. K. S. and Leung, C. K. Y. (2000) Price Volatility of Commercial And Residential Property, Journal of Real Estate Finance and Economics, 20, 1, 2536

Leahy, J. V. and Whited, T. M. (1996) the Effect of Uncertainty on Investment: Some stylized facts, Journal of Money, Credit, and Banking, 28, 1, 64-83

Lentz and Tse (1995) An Option Pricing Approach to the Valuation of Real Estate Contaminated with Hazardous Materials, Journal of Real Estate Finance and Economics, 10, 121-144

McDonald, R. \& Siegel, D (1986) The Value of Waiting to Invest, Quarterly Journal of Economics, 101, 707-727

McMillen, D. P. (1996) One Hundred Fifty Years of Land Values in Chicago: A Nonparametric Approach. Journal of Urban Economics, 40, 100-124

Mills, E. S. and Simenauer, R. (1996) New Hedonic Estimates of Regional Constant Quality house Prices, Journal of Urban Economics, 39, 209-215

Miyao, T (1993) Reexamination of the Economic Theory of Land Value, Journal of Japan Society of Civil Engineers, 470, 27-33

Nakamura, R. (1992.7), Empirical Problems in the hedonic approach, Journal of Japan Society of Civil Engineers, 449, 57-66

National Land Agency (2000), White Paper on Land. Tokyo: Japanese Government Press 
Pace, R., Barry. R. \& Sirmans, C. (1998) Spatial Statistics and Real Estate, Journal of Real Estate Finance and Economics, 17, 1, 5-13

Paddock, J. L., Siegel, D. R. and Smith, J. L. (1988) Option Valuation of Claims on Real Assets: The Case of Offshore Petroleum Leases, Quarterly Journal of Economics, 101, 479-508

Pindyck, R. and D. Rubinfeld. (1998), Econometric Models and Economic Forecasts (4th ed.). New York: McGraw-Hill.

Quan, D. C. and Titman, S. (1999) Do Real Estate Prices and Stock Prices Move Together? An Investment Analysis, Real Estate Economics, 27, 183-207

Quigg, L. (1993). Empirical Testing of Real Option-Pricing Models, Journal of Finance, 48, 2, 621-639

Riddiough, T. (1997). The Economic Consequences of Regulatory Taking Risk on Land Value and Development Activity, Journal of Urban Economics, 41, 56-77

Thorsnes, P. and McMillen, D. P (1998) Land Value and Parcel Size: A Semiparametric Journal of Real Estate Finance and Economics, 17, 3, 233-244

Titman (1985) Urban Land Prices under Uncertainty. The American Economic Review, 75, 3, 505-514

Trigeorgis, L. (1996). Real Options. Cambridge: MIT Press

Williams (1991) Real Estate Development as an Option. Journal of Real Estate Finance and Economics, 4, 191-208

Williams (1993) Equilibrium and Options on Real Assets. Review of Financial Studies, 6, $4,825-850$

Yai et al. (1992) A Basic Analysis on Land Pricing Structure in Commercial Areas, Journal of Japan Society of Civil Engineers, 449, 87-96

Yoshida, J. (1999). Effects of Uncertainty on the Investment Decision; An Examination of the Option-Based Investment Model Using Japanese Real Estate, Center for Real Estate Thesis,. Massachusetts Institute of Technology 